\title{
Disruption of steroidogenesis: cell models for mechanistic investigations and as screening tools
}

\author{
Alex Odermatt*, Petra Strajhar, Roger T. Engeli \\ Swiss Center for Human Toxicology and Division of Molecular and Systems Toxicology, \\ Department of Pharmaceutical Sciences, Pharmacenter, University of Basel, Klingelbergstrasse 50, \\ 4056 Basel, Switzerland \\ *Correspondence to: \\ Dr. Alex Odermatt, Division of Molecular and Systems Toxicology, Department of Pharmaceutical \\ Sciences, Pharmacenter, University of Basel, Klingelbergstrasse 50, 4056 Basel, Switzerland, E- \\ mail: alex.odermatt@unibas.ch
}

Key words: adrenal; testis; ovary; Leydig; granulosa; endocrine disrupting chemical; in vitro 


\begin{abstract}
In the modern world, humans are exposed during their whole life to a large number of synthetic chemicals. Some of these chemicals have the potential to disrupt endocrine functions and contribute to the development and/or progression of major diseases. Every year approximately 1000 novel chemicals, used in industrial production, agriculture, consumer products or as pharmaceuticals, are reaching the market, often with limited safety assessment regarding potential endocrine activities. Steroids are essential endocrine hormones, and the importance of the steroidogenesis pathway as a target for endocrine disrupting chemicals (EDCs) has been recognized by leading scientists and authorities. Cell lines have a prominent role in the initial stages of toxicity assessment, i.e. for mechanistic investigations and for the medium to high throughput analysis of chemicals for potential steroidogenesis disrupting activities. Nevertheless, the users have to be aware of the limitations of the existing cell models in order to apply them properly, and there is a great demand for improved cell-based testing systems and protocols. This review intends to provide an overview of the available cell lines for studying effects of chemicals on gonadal and adrenal steroidogenesis, their use and limitations, as well as the need for future improvements of cell-based testing systems and protocols.
\end{abstract}




\section{Introduction}

There is an increasing interest in the identification of chemicals that interfere with the endocrine system. The Endocrine Society defines an endocrine disrupting chemical (EDC) as an "exogenous chemical or mixture of chemicals that can interfere with any aspect of hormone action" [1]. It is important, in our opinion, to distinguish between transient influences followed by adaptation and disruption of endocrine functions leading to adverse health effects. This is considered by the European Union (EU) that defines an EDC as an "exogenous substance that causes adverse health effects in an intact organism, or its progeny, secondary to changes in endocrine function" $[2,3]$. The protection of human health and the environment is of high priority for major organizations and regulatory authorities. Regarding the large number of chemicals that need to be tested for potential endocrine disrupting effects, in programs such as REACH (Registration, Evaluation, Authorization and Restriction of Chemicals, http://ec.europa.eu/growth/sectors/chemicals/reach/index_en.htm), the EPA's EDSP (Environmental Protection Agency's Endocrine Disruptor Screening Program, http://www.epa.gov/endo/) or the FDA (U.S. Food and Drug Administration) guidelines for drug development (http:/www.fda.gov/Drugs/GuidanceComplianceRegulatoryInformation/Guidances/), it is important to first evaluate the most relevant chemicals, i.e. chemicals with evidence of causing adverse effects and for which relevant exposure is known or can be expected. Besides chemicals used in industrial production, agriculture, electronics, and consumer products, the safety of pharmaceuticals and food constituents need to be assessed. Thus, a huge number of chemicals need to be tested for a wide range of possible adverse effects, including such caused by a disruption of steroid hormone action.

Amongst other endocrine hormones, steroids play crucial roles in the regulation of nearly all physiological processes. Several reports provided evidence for an association of disturbances of steroid hormone action caused by exogenous chemicals with developmental defects [4], infertility 
and reproductive dysfunctions [5, 6], testicular, prostate and breast cancer [7-9], obesity and diabetes [10-12], immune disorders and neurobehavioral and learning dysfunctions [13, 14]. Further research is needed to identify other chemicals disrupting steroid hormone action, to evaluate the mechanisms by which such chemicals disrupt steroid hormone action, and to assess the critical exposure windows and concentrations that are relevant regarding development and progression of diseases.

For the initial endocrine safety testing of a large number of chemicals, improved in silico and in vitro assays are needed to facilitate the prioritization of chemicals for further toxicological investigations. Cell-based steroidogenesis assays represent a suitable starting point to assess disturbances of steroid biosynthesis, induced by direct inhibition of steroidogenic enzymes or by affecting their expression. The advantage of the cell-based models is that several enzymes and receptors required for the synthesis of steroids, as well as the signaling pathways regulating their activities, may be covered in a single assay. In addition to the identification of potentially hazardous chemicals, the cell-based steroidogenesis assays allow first mechanistic insights into the mode-ofaction of EDCs; however, the users need to be aware of the limitations of the system applied in order to avoid drawing inappropriate conclusions and over-interpretation of results. This review focuses on the cell lines that are available to study steroidogenesis, their advantages and limitations, and the existing gaps for early safety testing of chemicals disrupting steroid homeostasis.

\section{Steroidogenesis}

Primary organs that are producing steroids from their precursor cholesterol include the adrenal glands and the gonads, with testes in males and ovaries in females. Additionally, in females the placenta produces high amounts of progesterone during pregnancy [15]. Other organs expressing steroidogenic enzymes include the brain [16, 17], the intestinal tract [18] and the skin [19]. 
However, the steroids produced in these tissues seem to be restricted to affect local rather than systemic levels, and the relevance of steroidogenesis in these tissues will not be discussed.

The major steroidogenic organs synthesize steroids de novo from cholesterol that is either produced directly by the cell from acetyl-CoA or taken up from dietary cholesterol bound to low-density lipoproteins (LDL) in the circulation (for a comprehensive review see [20]). Cholesterol can be esterified, stored in lipid droplets and be released by the activity of hormone-sensitive lipase. The rate-limiting step in adrenal and gonadal steroidogenesis is the uptake of cholesterol into the mitochondria. The steroidogenic acute regulatory protein (StAR) facilitates the transfer of cholesterol from the outer to the inner mitochondrial membrane, and its conversion to pregnenolone by the cytochrome P450 side chain cleavage enzyme (P450scc, CYP11A1) in cooperation with adrenodoxin reductase that functions as an electron transfer protein of CYP11A1 [20]. Dependent on the organ, pregnenolone is then further converted by tissue- and cell type-specific enzymes into androgens, estrogens, glucocorticoids or mineralocorticoids.

The cortex of the adult human adrenals is responsible for the production of mineralocorticoids in the zona glomerulosa, glucocorticoids in the zona fasciculata and precursors of active androgens in the zona reticularis (Figure 1). The zona reticularis expresses high levels of CYP17A1 [21], which possesses $17 \alpha$-hydroxylase activity for the formation of $17 \alpha$-hydroxypregnenolone and 17,20-lyase activity for the subsequent formation of dehydroepiandrosterone (DHEA). The high expression of cytochrome b5, in the presence of cytochrome P450 reductase, allows efficient 17,20-lyase activity that is needed for the production of DHEA [20,22]. Additionally, the zona reticularis expresses high levels of the steroid sulfotransferase SULT2A1 that is responsible for the formation of sulfated DHEA (DHEAS) [23], the most abundant steroid in human blood [24]. Importantly, 3 $\beta$ hydroxysteroid dehydrogenase $2(3 \beta-\mathrm{HSD} 2)$ is expressed in the zona reticularis at very low levels, thus leading to only low amounts of $\Delta 4$-androstene-3,17-dione (androstenedione) production [20]. Since $17 \beta$-hydroxysteroid dehydrogenase type 3 (17 $\beta$-HSD3) is absent and 17 $\beta$-HSD5 (AKR1C3) 
expressed at very low levels in the zona reticularis $[21,25]$, only very low levels of testosterone are produced by the adrenals [26, 27]. CYP21A2 is absent in the zona reticularis, thus no mineralocorticoids and glucocorticoids are formed in this layer [20].

In the zona fasciculata pregnenolone is converted to 17 -hydroxypregnenolone by CYP17A1, and pregnenolone and 17 -hydroxypregnenolone are converted to progesterone and $17 \alpha-$ hydroxyprogesterone, respectively, by $3 \beta-\mathrm{HSD} 2$. Most of the progesterone formed is also $17 \alpha-$ hydroxylated. Further metabolism by CYP21A2 leads to 11-deoxycortisol and lower amounts of 11-deoxycorticosterone that are further converted by CYP11B1, which is specifically expressed in this zone, into cortisol and corticosterone, respectively [20, 28]. Cytochrome b5 is expressed at background levels in the zona fasciculata [21], resulting in very low CYP17A1 17,20-lyase activity and thus low amounts of DHEA formation [20]. The zona fasciculata expresses the melanocortin-2receptor and is therefore responsive to adrenocorticotrophic hormone $(\mathrm{ACTH})[20,28]$.

The zona glomerulosa does not express CYP17A1, and pregnenolone is converted to progesterone by $3 \beta$-HSD2 and further to 11-deoxycorticosterone by CYP21A2, and to corticosterone and aldosterone by CYP11B2. In the adrenals, CYP11B2 expression is restricted to the zona glomerulosa and the production of aldosterone is regulated by angiotensin II receptors [20].

The human fetal adrenals produce high amounts of DHEAS, which is abolished soon after birth where the adrenals mainly consist of a zona glomerulosa and a zona fasciculata and thus produce mineralocorticoids and glucocorticoids [29]. The zona reticularis actively starts producing adrenal androgens at adrenarche at around 6-8 years of age and reaching peak levels in the third decade of life, before declining gradually [30, 31].

In the testis, steroidogenesis is restricted to the Leydig cells. They convert pregnenolone by CYP17A1 into 17 $\alpha$-hydroxypregenenolone and further to DHEA (Figure 2). Because of the high expression of $3 \beta-H S D 2$ and $17 \beta-H S D 3$ but the absence of SULT2A1, DHEA is not sulfated and therefore further converted to androstenediol, or by a lower extent to androstenedione, and 
subsequently to testosterone in Leydig cells [20, 32]. Furthermore, CYP21A2, CYP11B1 and CYP11B2 are absent, thus no gluco- and mineralocorticoids are produced. Testicular steroidogenesis is under the control of human chorionic gonadotropin (hCG) and luteinizing hormone (LH).

In the ovaries, steroidogenesis is mediated by theca and granulosa cells. The granulosa cells are located in the avascular cellular compartment surrounding the oocyte, and the theca cells reside in the ovarian stroma; these cellular compartments are separated by the basal membrane. The theca and granulosa cells both express StAR and CYP11A1 [33]. Because granulosa cells do not express CYP17A1 [34], they can synthesize pregnenolone from cholesterol and they convert it further to progesterone in the corpus luteum (Figure 3) [20]. However, for the production of estrogens, pregnenolone needs to be secreted from the granulosa cells and taken up by the theca cells, or it is produced directly by the theca cells, to form DHEA. The theca cells express $3 \beta-H S D 2$ and convert DHEA into androstenedione [35]. Androstenedione is then delivered back to the granulosa cells for the aromatase-dependent production of estrogens [34]. Granulosa cells also express 17 $\beta$-HSD1, which is needed for the conversion of estrone into estradiol. There are cycle-dependent changes in ovarian steroidogenesis: in the luteal phase the luteinized granulosa cells are supplied with sufficient cholesterol, due to enhanced vascularization of the previously avascular compartment, and elevated LH levels enhance the expression of CYP11A1 and 3 $\beta$-HSD2, resulting in the synthesis of high amounts of progesterone [33]. In the follicular phase, follicle stimulating hormone (FSH) enhances the expression of aromatase and 17ß-HSD1 for the production of increased amounts of estradiol from theca cell-derived androstenedione. LH also activates LH receptors on theca cells to induce CYP17A1 expression, thereby enhancing androgen precursors for estrogen production by granulosa cells. Thus, a tight control of the cooperation of granulosa and theca cell function is essential for the appropriate regulation of estradiol synthesis. 


\section{Leydig cell models to investigate steroidogenesis}

Three independent large epidemiological studies revealed a decline in male serum testosterone levels in the general population [36-38]. Obesity was identified as a contributing factor for some but not all observations [39]. Increasing evidence suggests that exposures to EDCs contribute to male reproductive diseases and that prevention of EDC exposures may reduce the burden of male reproductive health problems [40]. As an example, cryptorchidism is a typical impairment following exposure to antiandrogenic chemicals during male sexual development [41]. Evidence was provided that levels of polybrominated diphenyl ethers (PBDEs) in human breast milk are associated with congenital cryptorchidism, although a contribution of other environmental factors cannot be excluded [42]. PDBEs have been shown in in vitro studies to directly antagonize AR activity $\left(\mathrm{IC}_{50}\right.$ of approximately $5 \mu \mathrm{M}$ for the mixture $\mathrm{DE}-71$ in an MDA-kb2 cell model expressing an AR-dependent luciferase reporter), and PDBEs additively and/or synergistically acted with other AR antagonistic compounds [43]. In in vivo studies PDBEs were shown to cause diminished growth of androgen-dependent tissues and a delay in puberty in the male rat following a pubertal exposure to 60 and $120 \mathrm{mg} / \mathrm{kg}$ /day of the DE-71 mixture [44]. Although such high exposure levels are unlikely to be reached in humans, the fact that humans are exposed to a multitude of compounds that may exert additive or synergistic effects emphasizes the need for the screening of chemicals for potential antiandrogenic effects. Because of the high public demand to reduce animal testing [45], improved cell-based assays are needed that allow the identification of chemicals disrupting the biosynthesis of steroids and the gaining of insights into the mode-of-action of such chemicals.

There are several immortalized rodent Leydig cell lines available for studying the regulation of steroidogenesis and to assess the impact of substances on steroid hormone production. However, to our knowledge, no human Leydig cell model is currently available that can be used for screening purposes and for toxicological studies. The available rodent Leydig cell lines have been derived from spontaneous tumors, upon experimental induction, or by in vitro immortalization. All of these 
cell systems have their limitations, as some of the steroidogenic enzymes and regulatory pathways are expressed at very low levels, if at all, likely as a result of the selection of cell clones that rapidly proliferate and because of dedifferentiation and loss of initial phenotype during prolonged cultivation.

Probably the most widely used immortalized Leydig cell line is MA-10 [46]. MA-10, the related MA-12, and the frequently used mLTC-1 are all derived from a C57Bl/6 Leydig cell tumor (designated M5480) [47]. These cell lines express LH receptors, and incubation with LH/hCG induces cAMP-dependent steroidogenesis. MA-10 cells also express mouse epidermal growth factor receptor (EGFR), which suppresses the hCG-induced steroidogenesis [48]. In both, MA-10 and mLTC-1, progesterone was the main steroid being produced, in line with the observation that the original tumor M5480 secreted progesterone but only very low amounts of testosterone, and the two cell lines displayed similar functional characteristics [47]. These observations suggest that $3 \beta$ hsd1 activity is dominant over Cyp17a1; therefore, pregnenolone is mainly converted into progesterone, with only minor amounts being further converted into androstenedione and testosterone. For these reasons, we propose that, using progesterone as a read-out, MA-10 and mLTC-1 cells can serve as suitable models to detect chemicals that affect the induction of steroidogenesis, the cAMP- and PKA-dependent signaling, or that directly inhibit the activities of StAR, Cyp11a1 or 3ß-hsd1. Due to the generation of only low amounts of testosterone by these cell lines, it is difficult to quantitatively assess the effect of chemicals that disrupt Cyp17a1 or 17ß-hsd3 activities. Nevertheless, the mRNA expression of key steroidogenic enzymes, including StAR, Cyp11a1 and $3 \beta$-hsd1, and to a lesser extent that of Cyp17a1 and $17 \beta$-hsd3, has been detected in MA-10 and mLTC-1 cells, and has been found to be affected upon exposure to chemical modulators [49-51].

MA-10 cells are applied by many investigators to study the impact of EDCs on the regulation of steroidogenesis; only a few will be mentioned in this review as examples. Recent studies on effects 
of bisphenol A (BPA) and its analogues on steroidogenesis in MA-10 cells suggested that tetrabromobisphenol A (TBBPA) concentration-dependently increased testosterone production at concentrations of $3 \mu \mathrm{M}$ and higher, while bisphenol S (BPS) had no effect and BPA and bisphenol F (BPF) induced testosterone secretion only at very high concentrations (30 and $100 \mu \mathrm{M}$, respectively) $[49,50]$. Following incubation of the cells for $48 \mathrm{~h}$ in the presence of $10 \mu \mathrm{M}$ of TBBPA, BPF or BPS an increased production of progesterone, and in the case of TBBPA of 17 $\alpha-$ hydroxyprogesterone and androstenedione, was measured. Furthermore, incubation of cells with 10 $\mu \mathrm{M}$ of BPF, BPS or TBBPA led to an elevated expression of $5 \alpha$-reductase 1 , indicating an increased production of $5 \alpha$-androstanedione and dihydrotestosterone. Importantly, the authors provided evidence that the TBBPA-mediated increase in testosterone production may be due to an inhibition of the efflux of androgen precursors required for testosterone synthesis by the multidrug resistance proteins MRP1 and MRP4 [50]. These observations emphasize the need to include steroid transporters in the assessment of EDCs and provide a further explanation for the low amount of testosterone produced by MA-10 cells under basal conditions.

MA-10 cells were also used to study direct effects of monophthalates on testicular steroidogenesis [52]. The LH-induced production of cAMP and progesterone was significantly inhibited in MA-10 cells treated with $30 \mu \mathrm{M}$ of mono(2-ethylhexyl)phthalate (MEHP), whereas testosterone production was significantly lowered upon incubation of the cells with $1 \mu \mathrm{M}$ MEHP, $3 \mu \mathrm{M}$ monobutylphthalate (MBP), $10 \mu \mathrm{M}$ mono-n-oxtylphthalate (MnOP) or $3 \mu \mathrm{M}$ monebenzylphthalate (MBeP) but not in the presence of monoethylphthalate (MEP) or monomethylphthalate (MMP) [52]. At the high concentration of $100 \mu \mathrm{M}$ MEHP the mRNA expression levels of StAR, Cyp11A1 and Cyp17A1 were down regulated. Interestingly, in mLTC-1 cells (not induced by LH) the phthalates di-n-butyl phthalate (DBP), MBP, di(2-ethylhexyl)phthalate (DEHP) and MEHP seemed to increase testosterone production at low concentrations of 0.001 to $0.1 \mu \mathrm{M}$ but inhibited at high

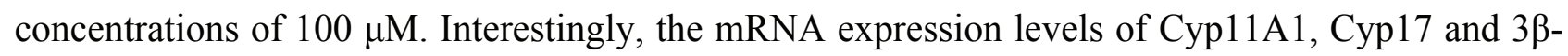


HSD1 were decreased even at concentrations as low as $0.1 \mu \mathrm{M}[53,54]$. Also, the impact of the major metabolites of MEHP and DEHP on the expression of steroidogenic genes has been analyzed, suggesting that the metabolite 2-ethylhexanal might inhibit Leydig cell testosterone formation, although this effect was only observed at high concentrations of $100 \mu \mathrm{M}$ [55]. The human relevance of such high concentrations are questionable and further research using lower concentrations are needed. Also, it should be noted that progesterone and testosterone were measured by ELISA in this study. Furthermore, a possible effect of phthalates on the efflux of androgen precursors or on cholesterol flux in MA-10 or in mLTC-1 cells has not been investigated.

Other studies focused on initial steps of steroidogenesis. Incubation of MA-10 and mLTC-1 cells with an organochlorine compound mixture resulted in a decreased expression of StAR, CYP11A1 and the adrenodoxin reductase, enzymes crucial for the production of pregnenolone from cholesterol [56]. The cAMP- and hCG-induced production of progesterone tended to be lower at 1 $\mu \mathrm{g} / \mathrm{ml}$ and was significantly lower at $10 \mu \mathrm{g} / \mathrm{ml}$ of organochlorine mixture. Also, the UV-filter chemical 2,2',4,4'-tetrahydroxybenzophenone (BP2), applied at $30 \mu \mathrm{M}$, was found to alter the expression of StAR, 3 $\beta$-hsd and Cyp17a1 and had opposite effects on Leydig cell steroidogenesis than thyroid hormone signaling [57]. Moreover, MA-10 cells were employed to test pesticide formulations that are widely used in agriculture. The pesticide mixture Roundup, a broad-spectrum systemic herbicide containing glyphosate (N-phosphonomethyl-glycine), inhibited the cAMP analogue-induced progesterone production at subcytotoxic concentrations of $25 \mu \mathrm{g} / \mathrm{ml}$ by decreasing the expression of the StAR protein [58]. Furthermore, the benzodiazepine midazolam was found to stimulate progesterone and testosterone production, measured by radio-immunoassay, at the subcytotoxic concentrations of 30 and $150 \mu \mathrm{M}$ in primary mouse Leydig cells and in MA-10 cells by an induction of the expression of the peripheral-type benzodiazepine receptor and StAR, probably via a pathway involving protein kinase A (PKA) and protein kinase C (PKC) [59]. Murine mLTC-1 Leydig cells were used to further investigate the reproductive toxicity of perfluorooctanic 
acid (PFOA) that was observed in mice treated by gavage [60]. Exposure of mLTC-1 cells with 100 $\mu \mathrm{M}$ PFOA decreased Cyp11a1 mRNA and protein expression and at $300 \mu \mathrm{M}$ PFOA progesterone production was significantly decreased. Also, StAR protein seemed to be decreased, likely as a result of oxidative stress caused by PFOA exposure $[60,61]$. The mycotoxin zearalenone at concentrations of $5 \mu \mathrm{M}$ was suggested to affect steroidogenesis in mLTC-1 cells by disrupting lipid metabolism and inducing endoplasmic reticulum stress-mediated apoptosis [62, 63]. Furthermore, the polybrominated diphenyl ether BDE-47 at a concentration of $1 \mu \mathrm{M}$ was found to decrease progesterone production via cAMP-PKA-dependent downregulation of CYP11a1 [64]. Thus, a multitude of chemicals were shown to affect inial steps of steroidogenesis by different mechanisms. It should be noted that in order to judge on the human relevance of the findings described above further investigations are required, as in most if these in vitro studies the concentrations applied were either much higher than concentrations measured in humans or data on such concentrations are not yet available.

Another mouse Leydig cell line, designated TTE1, was derived from transgenic mice, upon immortalization using a temperature-sensitive simian virus 40 (SV40) large T-antigen [65]. These cells can be grown at $33^{\circ} \mathrm{C}$ and differentiated at a non-permissive temperature of $39^{\circ} \mathrm{C}$. The cell model was used to study genes involved in Leydig cell differentiation characteristics, and the expression of the terminal enzyme of testosterone synthesis, $17 \beta$-hsd3, was confirmed at least on the mRNA level [66]. TTE1 cells were only used in very few studies, so for example to investigate the impact of diethylstilbestrol on the expression of steroidogenic genes [67, 68]. Diethylstilbestrol at concentrations of $50 \mathrm{nM}$ or higher decreased Cyp11a1 expression and, furthermore, diminished apoptotic cell death pathways and DNA repair capability, suggesting an increased carcinogenic potential of the exposed cells.

Mice transgenic for the SV40 T-antigen under the control of the inhibin- $\alpha$ promoter were used to establish the steroidogenic Leydig cell line BLT-1 [69]. BLT-1 cells responded well to LH and hCG 
by increased cAMP levels and enhanced production of progesterone. As observed for MA-10 and mLTC-1, BLT-1 cells are only producing very low amounts of testosterone, as measured by enzyme immunoassay. Regarding investigations into EDCs, the BLT-1 derived cell clone BLTK1 was used to study several environmental toxicants [70]. BLTK1 cells seem to express all key steroidogenic

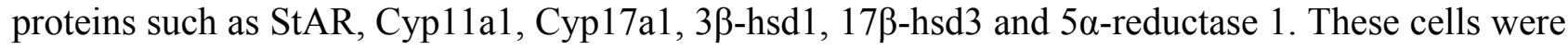
shown to respond to hCG and forskolin, which resulted in enhanced cAMP production and expression of steroidogenic genes. An elevated production of progesterone and testosterone was indicated by enzyme immuno assays measurements. The antifungals prochloraz $(30 \mu \mathrm{M})$ and triclosan $(30 \mu \mathrm{M})$ seemed to decrease the hCG-induced testosterone production, whereas MEHP $(300 \mu \mathrm{M})$ and atrazine (at concentrations of $30 \mu \mathrm{M}$ or higher) promoted basal testosterone formation but inhibited the hCG-dependent testosterone synthesis. Furthermore, the triazine herbicides atrazine, simazine, propazine and terbuthylazine were reported to enhance progesterone and testosterone production in BLTK1 cells at high concentrations (with significant effects observed at $100 \mu \mathrm{M}$ or higher), effects explained by the altered expression of steroidogenic genes [71]. However, in these studies very high concentrations of questionable human relevance were used.

The non-tumor mouse epithelial Leydig cell line TM3 was originally derived from the testis of an immature Balb/c mouse [72]. TM3 cells respond to $\mathrm{LH}$, but not FSH, with an increased cAMP production [73]. Evidence was provided that LH and EGF are involved in the regulation of cyclindependent kinase $5(\mathrm{Cdk} 5)$ expression and activity, and that this signaling pathway modulates hormonally stimulated testicular steroidogenesis [74]. Furthermore, LRH-1 was found to regulate Cyp19a1 expression via promoter II in multiple testis cell types [75]. Additionally, a role for hypoxia-inducible factor-1 $\alpha$ by mediating hypoxia-dependent changes on steroidogenesis by regulating the transcriptional expression of $3 \beta$-hsd1 was reported [76]. The $\mathrm{C} 1 \mathrm{q}$ and tumor necrosis factor-related protein (CTRP3) was found to induce testosterone production by increasing cAMP 
and phosphorylation of cAMP response element-binding protein (CREB) by PKA and subsequently enhancing the expression of StAR and Cyp11a1 [77]. TM3 cells express V1 type arginine vasopressin receptors that seem to act independent of the adenylate cyclase system [78] and calcitonin receptors, which mediate calcium influx and stimulate cAMP formation and testosterone secretion [79]. They also express inhibin/activin $\beta$-A subunits and activin receptors II and IIB [80]. A role for the Src tyrosine kinase in the regulation of phosphodiesterase PDE4 activity and the production of cAMP was reported [81]. TM3 cells mainly produce progesterone, and only minor amounts of testosterone (own observations), suggesting that they can serve as a model to study early steps of the regulation of steroidogenesis and direct inhibition of the activities of StAR, Cyp11a1 and $3 \beta$-hsd1.

The TM3 mouse Leydig cell line is frequently used to study the impact of environmental pollutants on testicular toxicity and on alterations in steroidogenesis. A study on gap junctional intercellular communication in TM3 cells showed inhibitory effects by estradiol and diethylstilbestrol via an estrogen receptor (ER)-dependent mechanism [82]. Interestingly, similar effects were observed at $10 \mathrm{pM}$ and $10 \mu \mathrm{M}$ concentrations for both diethylstilbestrol and estradiol, and these effects were fully reversed in the presence of an ER antagonist. Incubation of TM3 cells with diesel exhaust particles led to a reduced expression of $\mathrm{ER} \alpha$ (at $0.1 \mu \mathrm{g} / \mathrm{ml}$ particle concentration) and an induction of Cyp1a1 (at $1 \mu \mathrm{g} / \mathrm{ml}$ ) [83]. A transcriptomics analysis was performed on the impact of 1 and 5 $\mathrm{mM}$ methoxyacetic acid, the active metabolite of the industrial chemical ethylene glycol monomethyl ether, on TM3 cells revealing alterations in steroidogenesis, inflammation reactions and metabolic functions [84]. It needs to be noted that these concentrations are very high, and thus the human relevance is questionable. Two recent studies provided evidence for a protective role of the activation of the transcription factor Nrf2 towards the toxicity caused by the phthalate DBP, indicating the importance of the antioxidant defence system to protect Leydig cells from toxic chemicals $[85,86]$. Studies on chemicals affecting testosterone production in TM3 cells are rather 
uncertain, since these cells produce very low amounts. Furthermore, results on changes in testosterone production obtained using ELISA kits should be confirmed using quantification by GC-MS or LC-MS.

I-10 clonal Leydig cells were originally obtained from a spontaneous mouse testicular tumor [87]. Like other mouse Leydig cell lines described above, I-10 were reported to mainly produce progesterone, which was stimulated by cAMP [88], although not as efficient as in MA-10 and mLTC-1 cells. I-10 Leydig cancer cells were scarcely used for the assessment of EDCs. A study on PCBs showed enhanced CYP19a1 expression in mouse I-10 Leydig and human H295R adrenal cells following incubation for $24 \mathrm{~h}$ with the high concentration of $10 \mu \mathrm{M}$ PCB126 [89]. Interestingly, this effect was blunted in hCG and cAMP analogue-treated cells, and the authors proposed a role for AhR in these effects. Similarly, the mouse Leydig tumor cell line K28 was applied only in a few studies, including the investigation of the time-dependent induction of StAR mRNA expression and progesterone production by 9-cis and all-trans of retinoic acid (increases at concentrations greater than $10 \mathrm{nM}$ ) [90], the impact of LH on the expression of Nur77 (NR4A1) [91], the effect of $1 \mu \mathrm{M}$ BPA under serum-free conditions for $24 \mathrm{~h}$ on the induction of Nur77 expression and the production of progesterone [92], as well as the stimulating effects of $30 \mu \mathrm{M}$ cadmium chloride on CREB protein phosphorylation and StAR expression [93].

The rat Leydig tumor interstitial cell line R2C displays high StAR expression and produces high amounts of progesterone [94-96]. The high expression of StAR, Cyp1lal and 3 $\beta$-hsd1 was confirmed by RT-PCR and Western blot [97] and the production of progesterone was detected by ELISA and RIA measurements [98, 99]. The expression of Cyp17a1 and the production of testosterone have been reported [97-99]; however, a general problem with antibody-based quantification of proteins and steroids remains the often limited specificity of the antibodies used [100]. Thus, testosterone production by R2C cells should be confirmed using quantification by GCMS or LC-MS. An interesting property of R2C cells is that they are insensitive to cAMP regulation 
and do not require trophic stimulation to produce progesterone, which might be explained by a constitutively activated downstream signaling pathway $[95,101]$. Because of the constitutive production of progesterone, these cells are suitable to test chemicals that directly inhibit the activity of StAR, Cyp11a1 or $3 \beta$-hsd1. On the other side, this cell line is not suitable to study chemicals affecting the induction of steroidogenesis due to the lack of sensitivity of the involved signaling pathways.

$\mathrm{R} 2 \mathrm{C}$ cells were used in a comparative study with MA-10 cells to assess effects of various phthalates on testosterone production measured by ELISA [98]. The phthalates MBP and MEHP significantly inhibited testosterone synthesis at concentrations of 1 and $3 \mu \mathrm{M}$, with $\mathrm{IC}_{50}$ values of 3 and $6 \mu \mathrm{M}$ respectively. Phthalates with shorter alkyl side chains were found to be less active or inactive. Interestingly, R2C cells express substantial levels of Cyp19a1, and this cell line has been applied to characterize aromatase inhibitors [102, 103]. A study on effects of BPA (concentrations of 0.1 to 10 $\mathrm{nM}$ ) on steroidogenesis suggested an up regulation of Cyp19a1 protein expression and activity, whereas testosterone synthesis was decreased [104]. Testosterone was measured by ELISA. Using $\mathrm{R} 2 \mathrm{C}$ cells the anabolic androgenic steroids nandrolone and stanozolol (at $1 \mu \mathrm{M}$ concentration) were shown to increase Cyp19a1 expression as well as estradiol production [105]. Further, these authors provided evidence for an additive effect of androgens and IGF-1 on R2C cell proliferation and aromatase expression. In contradiction, a recent study showed that treatment of $\mathrm{R} 2 \mathrm{C}$ cells with the androgen mibolerone up regulated the transcription factor DAX-1 and inhibited the expression and activity of Cyp19a1, in line with observations in old Fischer rats with spontaneous Leydig cell tumors where AR and DAX-1 were down regulated and Cyp19a1 was up regulated [106]. The reason for the discrepances of the above studies remains unclear and requires further research.

A major limitation for mechanistic investigations into the regulation of steroidogenesis in Leydig cells and the assessment of the impact of potential EDCs is the fact that currently no human Leydig cell model is available. There are considerable species differences in the functions of Leydig cells. 
For example, it has been shown that the expression level of LH receptors is an order of magnitude higher in rat compared with human Leydig cells, and that rat Leydig cells respond with hyperplasia to hCG, whereas human Leydig cells become hypertrophic [107-110]. Furthermore, rat Leydig cells express gonadotropin-releasing hormone, whereas mouse and human Leydig cells do not [111, $112]$.

Additionally, several studies demonstrated species-specific inhibition of testicular steroidogenesis by EDCs. Using organotypic primary culture systems, the phthalate MEHP at a concentration of 10 $\mu \mathrm{M}$ was shown to decrease testosterone production in rat but not in human fetal testis explants [113, 114]. Further support for species-specific effects of phthalates was provided by studies where rat and human fetal testes were xenografted into a host mouse or rat $[115,116]$. Treatment with di-nbutylphthalate (500 mg/kg per day for four days) inhibited steroidogenesis in animals with rat but not human xenografts. Also, diethylstilbestrol did not affect human fetal testicular steroidogenesis in the xenograft model [117] and in human fetal testis explants, in contrast to rat and mouse testis cultures $[118,119]$, a difference explained by the fact that ER $\alpha$ is expressed in rat and mouse but not in human fetal Leydig cells [117]. Moreover, the anti-diabetic drug metformin inhibited testosterone production at an order of magnitude higher concentrations in human compared with mouse testis explants [120]. In contrast, it was shown that BPA inhibited testosterone synthesis at 100 times lower concentrations in human compared with rat and mouse fetal testis explants [118]. These studies demonstrate important species-specific differences in the susceptibility of human, rat and mouse testes to xenobiotics and further emphasize the need to establish a human Leydig cell model for the investigations into the molecular mechanisms of steroidogenesis disruption.

\section{Cell-based systems to study effects of EDCs on ovarian steroidogenesis}

In the industrialized countries, there is an increasing incidence of reproductive disorders such as polycystic ovary syndrome (PCOS) [121], which is characterized by chronic anovulation and 
hyperandrogenism and results in hirsutism, infertility and menstrual disturbances. As with male infertility, there is evidence for the contribution of EDCs from consumer products or environmental pollutants to the increasing incidence of female reproductive disorders (for a recent comprehensive review see [122]). Several EDCs and potential EDCs have been detected in human samples, including follicular fluid, from the general population [123-127]. Exposure to EDCs likely contributes to sub-fecundity, ovarian failure and infertility, and affects reproductive behavior. Exposure to EDCs may contribute to ovulatory dysfunction by decreasing estradiol biosynthesis in granulosa cells or as abortifacients by disrupting progesterone production in luteal cells [128].

In vivo testing of EDCs for reproductive toxicity is mostly conducted in rodents, with fertility as a primary endpoint [129]. Alteration in serum steroid levels may indicate an adverse effect but it may also represent an adaptive response, thus often not providing sufficient information on the toxicity of a given chemical. Also, changes in circulating steroid levels may be due to a direct effect on steroidogenesis or an altered feedback regulatory system. Ex vivo tissue samples, e.g. whole ovaries or isolated individual follicles, can be used to study follicular development, ovulation and steroidogenesis, and assays using such samples can provide results on multiple fertility-related endpoints [130]. In order to allow high throughput analyses and to gain mechanistic insight into the action of EDCs, cultured cells are advantageous. Isolated primary theca and granulosa cells can be applied for functional studies, and they retain the normal responses and steroidogenic pathways [131]. Porcine and bovine primary cells can be isolated from ovaries obtained from the slaughterhouse or from ovaries of rodent animal models; however, there are significant speciesspecific differences in the steroidogenic pathways, which need to be taken into account when trying to extrapolate results to the human system. Human granulosa cells are mostly obtained from women undergoing in vitro fertilization; however, these cells are usually subjected to supraphysiological concentrations of hCG and FSH, and these cells can only be cultivated for a relatively short time [132]. For these reasons, there is a great demand for suitable human theca and granulosa cell lines 
to investigate a large number of individual EDCs at various concentrations and incubation time as well as mixtures of EDCs. The establishment of a theca cell line was not successful so far; in contrast, several granulosa cell lines are available for investigating effects of chemicals on steroidogenesis.

Granulosa cell lines are useful to study the impact of potential EDCs on progesterone synthesis as well as on the aromatase- and 17 $\beta$-HSD1-dependent production of estradiol upon incubation of these cells with androstenedione. There is a large number of human ovarian cancer cell lines available (for a recent review see [133]). Most of them express CYP19A1 and 17ß-HSD1 and their proliferation is stimulated by estrogens. Additionally, immortalized granulosa cell lines from various animal species and of human origin have been described [134].

Among the rodent granulosa cell lines, KK-1, GRM01 and GRM02 were found to produce progesterone, and retain responsiveness to cAMP, FSH and $\mathrm{LH} / \mathrm{hCG}$ [134]. KK-1 cells were derived from mice bearing an SV40 T-antigen driven by the inhibin- $\alpha$ promoter, and treatment of these cells with hCG, forskolin and FSH increased cAMP 10-fold, 40-fold and 2.6-fold, respectively, indicating enhanced steroidogenesis [135]. KK-1 cells were shown to express Cyp19a1 and 17 $\beta$-hsd1 and convert androstenedione to estradiol. The KK-1 cell line was used, for example, to study effects of phthalates on the stimulation of steroidogenesis [136]. The phthalate MEHP at high concentrations of $20-100 \mu \mathrm{M}$ stimulated basal steroid production in KK-1 granulosa cells, a finding confirmed in mLTC-1 Leydig cells. The expression of StAR and cAMP-mediated signaling did not seem to be affected, and the authors suggested that MEHP may stimulate steroidogenesis by enhanced cholesterol supply. Thus, KK-1 represents a mouse cell system to study granulosa steroidogenesis. GRM01 and GRM02 granulosa cell lines were established by transfection of murine granulosa cells with v-myc [137]. Both cell lines retained steroidogenic activity and were shown to express $3 \beta$-hsd 2 and 17 - -hsd1 [138]. GRM01 was able to produce both progesterone and estradiol de novo, whereas GRM02 produced progesterone but not estradiol [139]. 
However, aromatase activity was also demonstrated in GRM02 upon the addition of androstenedione or testosterone to the culture medium. Steroid production was induced in both GRM01 and GRM02 by LH/hCG, FSH, forskolin and cAMP analogs. Both cell lines also express inhibin- $\alpha$, which has a role in feedback regulation by inhibiting pituitary FSH secretion. They represent alternative murine cell models to study the impact of potential EDCs that act as direct inhibitors of enzymes involved in progesterone or estradiol production or of the signaling pathways involved in steroidogenesis in granulosa cells.

There are several human granulosa cell lines that are useful for the investigation of endogenous regulators of steroidogenesis as well as pathways involved in metabolic regulation, the regulation of cell proliferation and apoptotic pathways. The cell lines HGP53, HO23, HGL5, HTOG and SVOG were primarily used to study signaling pathways, which are involved in the regulation of steroidogenesis and effects on apoptosis as well as cell proliferation [140-145]. The immortalized human granulosa cell line COV434, initially isolated from a primary granulosa cell tumor, was shown to express FSH receptor and CYP19A1. In FSH supplemented medium COV434 was able to produce estradiol from androstenedione [146]. FSH and forskolin both stimulated steroidogenesis by induction of cAMP. Pharmacological inhibition of the FSH receptor was found to inhibit COV434 cell proliferation [147]. Furthermore, incubation of COV434 cells with soy isoflavones, considered to act as phytoestrogens, promoted cell proliferation [148]. Incubation with 5 to $50 \mu \mathrm{M}$ genistein led to increased expression of ER $\alpha$ and enhanced cell proliferation by repressing proapoptotic genes. The human relevance of these observations remain uncertain because of the low bioavailablity of oral intake of isoflavones.

The most widely used human ovarian granulosa-like tumor cell line is KGN. Progesterone production as well as CYP19A1- and 17ß-HSD1-dependent estradiol formation from androstenedione supplemented culture medium was found to be induced by FSH via induction of IGF-1 in KGN granulosa cells [149]. Additionally, several endogenous regulators, such as 
steroidogenic factor-1 (SF-1) [150], liver receptor homolog-1 (LRH-1) [151], AMP-kinase (AMPK)/sirtuin-1 (SIRT1) [152], oocyte-derived growth differentiation factor and bone morphogenic protein 15 [153], the Notch signaling patway [154] and the Hippo pathway [155], were shown to affect progesterone production and CYP19A1- and 17 $\beta$-HSD1-dependent estradiol synthesis.

Several investigators used the KGN granulosa cell line to address the impact of xenobiotics on steroid synthesis. Bisphenol-A (BPA) was found to activate peroxisome proliferator-activated receptor (PPAR) $\gamma$ and inhibit the FSH-stimulated insulin-like growth factor-1 (IGF1)-dependent induction of CYP19A1 expression and estradiol synthesis in KGN cells and in primary granulosa cells [156]. A significant blunting of the FSH-induced CYP19A1 expression was seen at $40 \mu \mathrm{M}$ whereas estradiol production was reduced after treatment with $80 \mu \mathrm{M}$ of BPA. The BPA concentrations applied are very high and human relevance of this findings remains uncertain. Another study found that BPA concentration-dependently down regulated CYP19A1 expression in KGN cells as well as in human fetal osteoblastic cells, with significant effects seen at $5 \mu \mathrm{M}$ [157]. Additionally, DEHP $(5 \mu \mathrm{M})$ and TCDD $(10 \mathrm{nM})$ were found to inhibit the FSH-induced estradiol synthesis and to enhance the AhR expression in a PPAR-dependent manner [158]. Another study found that atrazine and simazine at $10 \mu \mathrm{M}$ enhanced the stimulatory effect of transfected SF-1 on aromatase mRNA expression and activity in KGN cells [159]. Recently, the pesticide simazine was found to shorten anogenital distance and to decrease whole body, ovarian and uterine weights in offspring of pregnant mice treated with $5-500 \mu \mathrm{g} / \mathrm{kg}$ of this pesticide [160]. Simazine at a concentration of $1 \mathrm{nM}$ diminished the viability and proliferation of KGN granulosa cells. Interestingly, a U-shaped curve was observed, whereby concentrations of 100-1000 nM no longer inhibited cell viability and proliferation.

Currently, most studies on EDCs affecting ovarian steroidogenesis are conducted using tumor cell lines of granulosa origin, where several pathways may be altered compared with normal granulosa 
cells. This limitation needs to be considered in the interpretation of results. Also, most cell lines are cultivated in medium containing high glucose concentrations and fetal bovine serum as well as under hyperoxia, a situation clearly distinct from that of the physiological context and likely to affet metabolic pathways and steroid production. Another limitation is that currently no suitable human theca cell line is available. Since the production of steroids by the ovaries requires a tight cooperation of granulosa and theca cells, ideally a co-culture system of granulosa and theca cells should be applied for the investigation of ovarian steroidogenesis.

\section{Adrenal cell models to investigate disruption of steroidogenesis}

The adrenal glands play an essential role in the regulation of electrolyte and energy homeostasis [161]. An over production of glucocorticoids by the adrenal glands ultimately causes Cushing's syndrome, which is characterized by increased visceral adipose tissue, insulin resistance, skin and skeletal muscle atrophy, and impaired wound healing. In contrast, insufficient glucocorticoid production causes Addison's disease, characterized by hypotension, fatigue, muscle weakness, loss of body weight and depression. The clinical observations emphasize the importance of including the assessment of chemicals applied to humans (drugs, chemicals in food and personal care products) or released at high amounts into the environment for potential adrenal toxicity. In this respect, fatal adrenal isufficiency, due to unexpected severe adverse drug effects [162-165], is a known clinical problem that has been recognized by the FDA [166]. In contrast to the investigations of the safety of chemicals regarding reproductive and developmental endpoints, with a major focus on the disruption of sex steroid hormone action, the adrenal gland has been neglected in EDCs regulatory testing strategy, as recently discussed by Harvey [167]. However, there are several chemicals, e.g. drugs, chemicals contained in consumer products and environmental pollutants, that were shown to cause adrenal toxicity (for reviews see $[163,167,168]$ ), further emphasizing the necessity of testing chemicals for potential adrenal toxicity. 
Nevertheless, regarding the use of cell-based testing systems, there is a widely used human adrenal cell line, i.e. H295R. The OECD (Organization for Economic Cooperation and Development) published a guideline for the testing of chemicals using this cell line [169]. The H295R cell line was derived from the NCI-H295 cell line that was established from an adrenocortical carcinoma of a female patient [170]. The use of NCI-H295 cells was limited by the slow proliferation and the fact that they formed cell clusters in culture. Using GC-MS analysis and radio-immuno assays (RIA) NCI-H295 cells were shown to produce about 30 different steroids [170-174]. Importantly, this cell line was shown to express most of the major steroidogenic genes; it also expresses CYP11B2 and has the ability to produce aldosterone, mainly upon stimulation with angiotensin II or potassium. The parental NCI-H295 cells were used to derive the H295A cells [175] as well as the H295R cells [173]. H295R cells can further be distinguished as H295R-S1, H295R-S2 and H295R-S3 clones, depending on the cultivation conditions. H295R-S1 are cultivated in a medium containing Nuserum, H295R-S2 in a medium with the serum substitute Ultroser-G and H295R-S3 in a medium containing Cosmic calf serum [176]. Furthermore, three additional clones were derived from NCIH295, namely HAC13, HAC15 and HAC50 [176-178]. The NCI-H295 derived clonal cell lines all grow as adherent monolayers but show significant differences in the expression of steroidogenic enzymes, the response to endogenous regulators and the amounts of steroids synthesized, emphasizing the importance of the culture medium composition. Nevertheless, the NCI-H295 cell lines respond to angiotensin II and potassium by increased aldosterone production; however, their response to ACTH is either absent or very weak [179]. Besides the NCI-H295 clonal cell lines, no other human adrenal cell line with substantial steroidogenic properties has been reported to date.

Based on the secreted steroids and mRNA analyses the NCI-H295 clonal cell lines appeared to express all of the adrenocortical enzymes that were present in the original tumor including StAR,

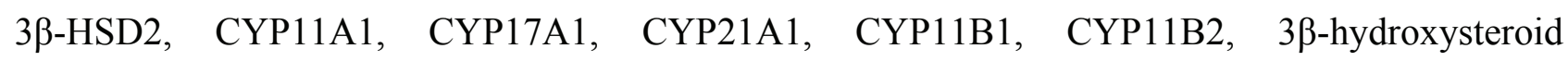
sulfotransferase and low levels of CYP19A1 [173, 178]. The expression pattern and steroids 
produced indicates that these cells represent characteristics of the different adrenal zones. It needs to be noted that the basal production of cortisol and aldosterone in H295R cells is low, indicating a low expression of CYP11B1 and CYP11B2 in the absence of inducers. However, treatment with endogenous regulators can enhance some zone-specific effects. Forskolin and cAMP analogues enhance the production of adrenal androgens (DHEA, DHEAS, androstenedione) and glucocorticoids (cortisol, 11-deoxycortisol, corticosterone), whereas angiotensin II, the primary regulator of the renin-angiotensin-aldosterone system, and potassium induce the production of aldosterone in $\mathrm{H} 295 \mathrm{R}$ cells $[171,172,180,181]$. It was shown that H295R cells mediate angiotensin II effects through angiotensin receptor 1 (AT1) [172, 179, 182-184]. In contrast, H295A do not express substantial levels of AT1 and lack sensitivity to angiotensin II [185]. NCI-H295 clonal cell lines show weak or absent response to ACTH due to the very low expression of melanocortin 2 receptor (MC2R) [177]. Interestingly, in H295R cells ACTH induced a transient increase in aldosterone but not in cortisol production. Thus, depending on whether the cells are used in the basal state or upon stimulation with various effective agonists, the adrenal cell lines may be used to study the effect of EDCs on the functions of the different adrenocortical zones.

Besides the human NCI-H295 clonal cell lines, mouse adrenal cell lines have been used in several studies on adrenal steroidogenesis. The mouse Y-1 cells were reported to exhibit characteristics of both zona fasciculata and zona glomerulosa, and they are able to produce corticosterone and aldosterone [173, 186-188]. Y-1 cells were shown to respond to ACTH with increased expression of steroidogenic genes and enhanced corticosterone production; however, the stimulatory effect was rather modest compared with that of isolated primary mouse adrenal cells [179, 189]. Later, two other cell lines, designated ATC1 and ATC7-L, established from adrenal tumors of two transgenic mice expressing the SV40 large T-antigen under the control of the akrlb7 promoter, have been described [190]. Both cell lines exhibited a typical phenotype of the zona fasciculata. They produced high amounts of corticosterone and retained responsiveness to ACTH. Incubation of these 
cells with ACTH increased SF-1 and decreased DAX-1 expression, providing an explanation for the observed stimulation of corticosterone production. Thus, ATC1 and ATC7-L represent useful cell models to study zona fasciculata specific function.

In contrast to the testicular and ovarian cell models, there is a human adrenal cell model (H295R) that has been recognized by the regulators for toxicity screening and resulted in an OECD test guideline for the evaluation of EDCs [169]. Therefore, a large number of studies applied the H295R cell model for the assessment of chemicals that cause disturbances of steroidogenesis, including pharmaceuticals, consumer products, food constituents and environmental pollutants [191-198], and it is out of the scope of this review to cover the findings of these studies. Currently, the OECD guideline only focuses on the use of H295R cells in their basal state and on the production of estradiol and testosterone as endpoints [199], two hormones not typically produced by the adrenals. Thus, there are limitations of the current protocol as well as in the use of the H295R cells and the exploitation of this cell model could be significantly extended. Interestingly, the measurement of the main adrenal steroids, i.e. adrenal androgens, glucocorticoids and mineralocorticoids, is currently not covered by the OECD guideline and an extended protocol to include the quantification of DHEA, cortisol and aldosterone needs to be validated [200, 201]. Other important steroids such as progesterone, 17 $\alpha$-hydroxyprogesterone, 11-deoxycorticosterone and 11-deoxycortisol should also be determined simultaneously with the major adrenal steroids in order to obtain a broader picture of disturbances caused by a given chemical.

Since in their basal state H295R cells produce only low amounts of cortisol and aldosterone, the cells should be used in the basal state to detect chemicals that induce steroidogenesis and upon treatment with specific agonists such as ACTH, angiotensin II and potassium [202] in order to detect chemicals that inhibit steroidogenesis. For the latter, the time point of adding a chemical is important. The pre-incubation or simultaneous addition of a chemical with an inducer may allow to identify chemicals that disrupt regulatory pathways of steroidogenesis. Incubation of a chemical 
following stimulation of the cells will allow to identify compounds that directly inhibit steroidogenic enzymes. Thus, different protocols need to be applied depending on the mode-ofaction of a given compound. Also, inclusion of appropriate reference compounds (positive and negative controls) and time course analysis of the steroid production would aid the interpretation of the data. Another important issue is the inclusion of measurements of the steroid concentrations in the complete medium at the time of the start of the experiment, as the amounts of these steroids are influenced by the composition of the serum used. Furthermore, the availability of LC-MS based methods allows to simultaneously quantify several steroid hormones and specific steroid pattern analysis can be performed for reference compounds and individual EDCs [203-206]. In many recent studies antibody-based detection methods have still been used for quantification of steroids. These methods often are lacking specificity due to cross-reactivity of the antibodies. Thus, GC-MS and LC-MS methods should not only allow more accurate quantification but allow the simultaneous assessment of multiple steroids.

A major limitation of the H295R cell system is the insensitivity towards ACTH. Thus, the establishment of an additional human adrenal cell line is required. Regarding ACTH response, murine ATC1 and ATC7-L cells may represent useful alternatives for testing until a suitable human cell system is available; however, species-specific differences in signaling pathways need to be taken into account.

\section{Conclusions and outlook}

Cell-based steroidogenesis models are highly valuable for mechanistic studies of chemicals disrupting steroidogenesis and allow an initial medium to high throughput assessment of the potential endocrine toxicity of chemicals. In contrast, to adrenal steroidogenesis, there is no commonly used cell line or standardized procedure to assess effects of chemicals on steroidogenesis in Leydig cells and ovarian cells. Future efforts should therefore aim at establishing a human 
Leydig cell line with the capability to respond to $\mathrm{LH}$ and produce testosterone. To investigate ovarian steroidogenesis, a human theca cell model is needed and, ideally, a theca granulosa coculture cell system responding to FSH should ideally be established, with the capability for de novo steroid synthesis up to the final step of estradiol production. Moreover, there is a need for an ACTH-sensitive human adrenal cell line.

In order to extend and improve the current cell-based testing protocols for studying chemicals that disrupt steroidogenesis and to facilitate the comparison of results from different laboratories, several general issues should be considered: 1) the description of experiments using steroidogenic cell lines should include passage number, cell density, incubation time and the composition of the complete medium used, including glucose concentration, possible use of antibiotics, amount of serum as well as the amount of steroids contained in the complete medium. Cells should only be used within certain passage numbers to guarantee comparable steroidogenic activity and responsiveness of the involved signaling pathways; 2) Ideally, the same positive and negative controls should be included in every experiment to verify the responsiveness of the cell batch used; 3) The cells should be used in the basal state as well as upon stimulation with specific inducers. Ideally, the same inducers, concentrations and conditions should be applied in different laboratories and experiments to allow a direct comparison of the results. The chemicals to be tested should be added prior to stimulation or simultaneously with the inducer in order to investigate whether the response to an inducer is blunted or potentiated, as well as following stimulation in order to detect direct effects on steroidogenic enzymes; 4) The quantification of steroid metabolites should be performed by GC-MS or LC-MS to assure specificity of the results. The major steroids should be quantified rather than a single steroid; and 5) another key issue remains the experimental concentration of a given chemical to be tested. A drawback of cell-based studies is the short duration of the incubation compared with humans who might be exposed for a long period of time. Also, often human exposure data is not available and concentrations of a given compound can vary 
significantly from its tissue concentration. Usually concentrations chosen for in vitro experiments are higher than those observed in humans. Nevertheless, it has to be distinguished between studies aiming at providing mechanistic information and studies for risk assessment. For the latter, it is crucial to choose concentrations that realistically can be reached after occupational exposure or in case of environmental toxicants after exposure in the general population. As suggested by Teeguarden and Hanson-Drury toxicity study exposures should be directly compared to human exposure if such data are available and qualification of a study as "low dose" in the absence of reliable human exposure data should be avoided [207].

Thus, there is still considerable room for improvement of the currently available cellular testing systems and the protocols for measurements of chemical-induced disturbances of steroidogenesis.

\section{Acknowledgements}

This work was supported by the Swiss National Science Foundation (31003A_159454), the Swiss Center for Applied Human Toxicology, and the Novartis Research Foundation.

\section{References}

[1] R.T. Zoeller, T.R. Brown, L.L. Doan, A.C. Gore, N.E. Skakkebaek, A.M. Soto, T.J. Woodruff, F.S. Vom Saal, Endocrine-disrupting chemicals and public health protection: a statement of principles from The Endocrine Society, Endocrinology, 153 (2012) 4097-4110.

[2] G.J. Nohynek, C.J. Borgert, D. Dietrich, K.K. Rozman, Endocrine disruption: fact or urban legend?, Toxicol Lett, 223 (2013) 295-305.

[3] T. Damstra, S. Barlow, A. Bergman, R.J. Kavlock, G. Van Der Kraak, eds., Global Assessment of the State-of-the-Science of Endocrine Disruptors, International Programme on Chemical Safety, WHO publication no. WHO/PCS/EDC/02.2, Geneva, Switzerland: World Health Organization (2002).

[4] R.E. Chapin, J. Adams, K. Boekelheide, L.E. Gray, Jr., S.W. Hayward, P.S. Lees, B.S. McIntyre, K.M. Portier, T.M. Schnorr, S.G. Selevan, J.G. Vandenbergh, S.R. Woskie, NTP- 
CERHR expert panel report on the reproductive and developmental toxicity of bisphenol A, Birth Defects Res B Dev Reprod Toxicol, 83 (2008) 157-395.

[5] R. Hauser, The environment and male fertility: recent research on emerging chemicals and semen quality, Semin Reprod Med, 24 (2006) 156-167.

[6] D.C. Luccio-Camelo, G.S. Prins, Disruption of androgen receptor signaling in males by environmental chemicals, J Steroid Biochem Mol Biol, 127 (2011) 74-82.

[7] B.A. Cohn, M.S. Wolff, P.M. Cirillo, R.I. Sholtz, DDT and breast cancer in young women: new data on the significance of age at exposure, Environ Health Perspect, 115 (2007) 1406-1414.

[8] S. De Coster, N. van Larebeke, Endocrine-disrupting chemicals: associated disorders and mechanisms of action, J Environ Public Health, 2012 (2012) 713696.

[9] A. Fucic, M. Gamulin, Z. Ferencic, J. Katic, M. Krayer von Krauss, A. Bartonova, D.F. Merlo, Environmental exposure to xenoestrogens and oestrogen related cancers: reproductive system, breast, lung, kidney, pancreas, and brain, Environ Health, 11 Suppl 1 (2012) S8.

[10] J.L. Carwile, K.B. Michels, Urinary bisphenol A and obesity: NHANES 2003-2006, Environ Res, 111 (2011) 825-830.

[11] L. Trasande, T.M. Attina, J. Blustein, Association between urinary bisphenol A concentration and obesity prevalence in children and adolescents, Jama, 308 (2012) 1113-1121.

[12] B.A. Neel, R.M. Sargis, The paradox of progress: environmental disruption of metabolism and the diabetes epidemic, Diabetes, 60 (2011) 1838-1848.

[13] M. Kajta, A.K. Wojtowicz, Impact of endocrine-disrupting chemicals on neural development and the onset of neurological disorders, Pharmacol Rep, 65 (2013) 1632-1639.

[14] B. Weiss, The intersection of neurotoxicology and endocrine disruption, Neurotoxicology, 33 (2012) 1410-1419.

[15] W.L. Miller, Steroid hormone biosynthesis and actions in the materno-feto-placental unit, Clin Perinatol, 25 (1998) 799-817.

[16] N.A. Compagnone, S.H. Mellon, Neurosteroids: biosynthesis and function of these novel neuromodulators, Front Neuroendocrinol, 21 (2000) 1-56.

[17] S.H. Mellon, C.F. Deschepper, Neurosteroid biosynthesis: genes for adrenal steroidogenic enzymes are expressed in the brain, Brain Res, 629 (1993) 283-292.

[18] G. Bouguen, L. Dubuquoy, P. Desreumaux, T. Brunner, B. Bertin, Intestinal steroidogenesis, Steroids, 103 (2015) 64-71.

[19] A. Slominski, B. Zbytek, G. Nikolakis, P.R. Manna, C. Skobowiat, M. Zmijewski, W. Li, Z. Janjetovic, A. Postlethwaite, C.C. Zouboulis, R.C. Tuckey, Steroidogenesis in the skin: implications for local immune functions, J Steroid Biochem Mol Biol, 137 (2013) 107-123. 
[20] W.L. Miller, R.J. Auchus, The molecular biology, biochemistry, and physiology of human steroidogenesis and its disorders, Endocr Rev, 32 (2011) 81-151.

[21] T. Suzuki, H. Sasano, J. Takeyama, C. Kaneko, W.A. Freije, B.R. Carr, W.E. Rainey, Developmental changes in steroidogenic enzymes in human postnatal adrenal cortex: immunohistochemical studies, Clin Endocrinol (Oxf), 53 (2000) 739-747.

[22] R.J. Auchus, T.C. Lee, W.L. Miller, Cytochrome b5 augments the 17,20-lyase activity of human P450c17 without direct electron transfer, J Biol Chem, 273 (1998) 3158-3165.

[23] R.J. Auchus, W.E. Rainey, Adrenarche - physiology, biochemistry and human disease, Clin Endocrinol (Oxf), 60 (2004) 288-296.

[24] J. Rege, Y. Nakamura, T. Wang, T.D. Merchen, H. Sasano, W.E. Rainey, Transcriptome profiling reveals differentially expressed transcripts between the human adrenal zona fasciculata and zona reticularis, J Clin Endocrinol Metab, 99 (2014) E518-527.

[25] J.S. Gell, B. Atkins, L. Margraf, J.I. Mason, H. Sasano, W.E. Rainey, B.R. Carr, Adrenarche is associated with decreased 3 beta-hydroxysteroid dehydrogenase expression in the adrenal reticularis, Endocr Res, 22 (1996) 723-728.

[26] J. Rege, Y. Nakamura, F. Satoh, R. Morimoto, M.R. Kennedy, L.C. Layman, S. Honma, H. Sasano, W.E. Rainey, Liquid chromatography-tandem mass spectrometry analysis of human adrenal vein 19-carbon steroids before and after ACTH stimulation, J Clin Endocrinol Metab, 98 (2013) 1182-1188.

[27] Y. Nakamura, P.J. Hornsby, P. Casson, R. Morimoto, F. Satoh, Y. Xing, M.R. Kennedy, H. Sasano, W.E. Rainey, Type 5 17beta-hydroxysteroid dehydrogenase (AKR1C3) contributes to testosterone production in the adrenal reticularis, J Clin Endocrinol Metab, 94 (2009) 2192-2198.

[28] P. Mulatero, K.M. Curnow, B. Aupetit-Faisant, M. Foekling, C. Gomez-Sanchez, F. Veglio, X. Jeunemaitre, P. Corvol, L. Pascoe, Recombinant CYP11B genes encode enzymes that can catalyze conversion of 11-deoxycortisol to cortisol, 18-hydroxycortisol, and 18-oxocortisol, J Clin Endocrinol Metab, 83 (1998) 3996-4001.

[29] W.L. Miller, Androgen synthesis in adrenarche, Rev Endocr Metab Disord, 10 (2009) 3-17.

[30] S. Dharia, A. Slane, M. Jian, M. Conner, A.J. Conley, R.M. Brissie, C.R. Parker, Jr., Effects of aging on cytochrome b5 expression in the human adrenal gland, J Clin Endocrinol Metab, 90 (2005) 4357-4361.

[31] L.N. Parker, Adrenarche, Endocrinol Metab Clin North Am, 20 (1991) 71-83.

[32] C.E. Fluck, W.L. Miller, R.J. Auchus, The 17, 20-lyase activity of cytochrome p450c17 from human fetal testis favors the delta5 steroidogenic pathway, J Clin Endocrinol Metab, 88 (2003) 3762-3766. 
[33] M. Jamnongjit, S.R. Hammes, Ovarian steroids: the good, the bad, and the signals that raise them, Cell Cycle, 5 (2006) 1178-1183.

[34] R. Voutilainen, J. Tapanainen, B.C. Chung, K.J. Matteson, W.L. Miller, Hormonal regulation of P450scc (20,22-desmolase) and P450c17 (17 alpha-hydroxylase/17,20-lyase) in cultured human granulosa cells, J Clin Endocrinol Metab, 63 (1986) 202-207.

[35] I. Hanukoglu, Steroidogenic enzymes: structure, function, and role in regulation of steroid hormone biosynthesis, J Steroid Biochem Mol Biol, 43 (1992) 779-804.

[36] A.M. Andersson, T.K. Jensen, A. Juul, J.H. Petersen, T. Jorgensen, N.E. Skakkebaek, Secular decline in male testosterone and sex hormone binding globulin serum levels in Danish population surveys, J Clin Endocrinol Metab, 92 (2007) 4696-4705.

[37] A. Perheentupa, J. Makinen, T. Laatikainen, M. Vierula, N.E. Skakkebaek, A.M. Andersson, J. Toppari, A cohort effect on serum testosterone levels in Finnish men, Eur J Endocrinol, 168 (2013) 227-233.

[38] T.G. Travison, A.B. Araujo, A.B. O'Donnell, V. Kupelian, J.B. McKinlay, A population-level decline in serum testosterone levels in American men, J Clin Endocrinol Metab, 92 (2007) 196-202. [39] C. Wang, G. Jackson, T.H. Jones, A.M. Matsumoto, A. Nehra, M.A. Perelman, R.S. Swerdloff, A. Traish, M. Zitzmann, G. Cunningham, Low testosterone associated with obesity and the metabolic syndrome contributes to sexual dysfunction and cardiovascular disease risk in men with type 2 diabetes, Diabetes Care, 34 (2011) 1669-1675.

[40] A. Bergman, J.J. Heindel, T. Kasten, K.A. Kidd, S. Jobling, M. Neira, R.T. Zoeller, G. Becher, P. Bjerregaard, R. Bornman, I. Brandt, A. Kortenkamp, D. Muir, M.N. Drisse, R. Ochieng, N.E. Skakkebaek, A.S. Bylehn, T. Iguchi, J. Toppari, T.J. Woodruff, The impact of endocrine disruption: a consensus statement on the state of the science, Environ Health Perspect, 121 (2013) A104-106.

[41] L.E. Gray, Jr., V.S. Wilson, T. Stoker, C. Lambright, J. Furr, N. Noriega, K. Howdeshell, G.T. Ankley, L. Guillette, Adverse effects of environmental antiandrogens and androgens on reproductive development in mammals, Int J Androl, 29 (2006) 96-104; discussion 105-108.

[42] K.M. Main, H. Kiviranta, H.E. Virtanen, E. Sundqvist, J.T. Tuomisto, J. Tuomisto, T. Vartiainen, N.E. Skakkebaek, J. Toppari, Flame retardants in placenta and breast milk and cryptorchidism in newborn boys, Environ Health Perspect, 115 (2007) 1519-1526.

[43] F. Orton, S. Ermler, S. Kugathas, E. Rosivatz, M. Scholze, A. Kortenkamp, Mixture effects at very low doses with combinations of anti-androgenic pesticides, antioxidants, industrial pollutant and chemicals used in personal care products, Toxicol Appl Pharmacol, 278 (2014) 201-208. 
[44] T.E. Stoker, R.L. Cooper, C.S. Lambright, V.S. Wilson, J. Furr, L.E. Gray, In vivo and in vitro anti-androgenic effects of DE-71, a commercial polybrominated diphenyl ether (PBDE) mixture, Toxicol Appl Pharmacol, 207 (2005) 78-88.

[45] T. Hartung, Toxicology for the twenty-first century, Nature, 460 (2009) 208-212.

[46] M. Ascoli, D. Puett, Gonadotropin binding and stimulation of steroidogenesis in Leydig tumor cells, Proc Natl Acad Sci U S A, 75 (1978) 99-102.

[47] R.V. Rebois, Establishment of gonadotropin-responsive murine leydig tumor cell line, J Cell Biol, 94 (1982) 70-76.

[48] M. Ascoli, Regulation of gonadotropin receptors and gonadotropin responses in a clonal strain of Leydig tumor cells by epidermal growth factor, J Biol Chem, 256 (1981) 179-183.

[49] M.J. Roelofs, M. Berg, T.F. Bovee, A.H. Piersma, M.B. Duursen, Structural bisphenol analogues differentially target steroidogenesis in murine MA-10 Leydig cells as well as the glucocorticoid receptor, Toxicology, 329 (2015) 10-20.

[50] A.C. Dankers, M.J. Roelofs, A.H. Piersma, F.C. Sweep, F.G. Russel, M. van den Berg, M.B. van Duursen, R. Masereeuw, Endocrine disruptors differentially target ATP-binding cassette transporters in the blood-testis barrier and affect Leydig cell testosterone secretion in vitro, Toxicol Sci, 136 (2013) 382-391.

[51] M.T. Dyson, M.P. Kowalewski, P.R. Manna, D.M. Stocco, The differential regulation of steroidogenic acute regulatory protein-mediated steroidogenesis by type I and type II PKA in MA10 cells, Mol Cell Endocrinol, 300 (2009) 94-103.

[52] R.A. Clewell, J.L. Campbell, S.M. Ross, K.W. Gaido, H.J. Clewell, 3rd, M.E. Andersen, Assessing the relevance of in vitro measures of phthalate inhibition of steroidogenesis for in vivo response, Toxicol In Vitro, 24 (2010) 327-334.

[53] X. Chen, Q.H. Zhou, L. Leng, Z.R. Sun, N.J. Tang, Effects of di(n-butyl) and monobutyl phthalate on steroidogenesis pathways in the murine Leydig tumor cell line MLTC-1, Environ Toxicol Pharmacol, 36 (2013) 332-338.

[54] X. Chen, Y.N. Liu, Q.H. Zhou, L. Leng, Y. Chang, N.J. Tang, Effects of low concentrations of di-(2-ethylhexyl) and mono-(2-ethylhexyl) phthalate on steroidogenesis pathways and apoptosis in the murine leydig tumor cell line MLTC-1, Biomed Environ Sci, 26 (2013) 986-989.

[55] C.D. Piche, D. Sauvageau, M. Vanlian, H.C. Erythropel, B. Robaire, R.L. Leask, Effects of di(2-ethylhexyl) phthalate and four of its metabolites on steroidogenesis in MA-10 cells, Ecotoxicol Environ Saf, 79 (2012) 108-115. 
[56] A.N. Enangue Njembele, J.L. Bailey, J.J. Tremblay, In vitro exposure of Leydig cells to an environmentally relevant mixture of organochlorines represses early steps of steroidogenesis, Biol Reprod, 90 (2014) 118.

[57] Y. Kim, J.C. Ryu, H.S. Choi, K. Lee, Effect of 2,2',4,4'-tetrahydroxybenzophenone (BP2) on steroidogenesis in testicular Leydig cells, Toxicology, 288 (2011) 18-26.

[58] L.P. Walsh, C. McCormick, C. Martin, D.M. Stocco, Roundup inhibits steroidogenesis by disrupting steroidogenic acute regulatory (StAR) protein expression, Environ Health Perspect, 108 (2000) 769-776.

[59] E.C. So, Y.T. Chang, C.H. Hsing, P.W. Poon, S.F. Leu, B.M. Huang, The effect of midazolam on mouse Leydig cell steroidogenesis and apoptosis, Toxicol Lett, 192 (2010) 169-178.

[60] H. Zhang, Y. Lu, B. Luo, S. Yan, X. Guo, J. Dai, Proteomic analysis of mouse testis reveals perfluorooctanoic acid-induced reproductive dysfunction via direct disturbance of testicular steroidogenic machinery, J Proteome Res, 13 (2014) 3370-3385.

[61] Z. Shi, Y. Feng, J. Wang, H. Zhang, L. Ding, J. Dai, Perfluorododecanoic acid-induced steroidogenic inhibition is associated with steroidogenic acute regulatory protein and reactive oxygen species in cAMP-stimulated Leydig cells, Toxicol Sci, 114 (2010) 285-294.

[62] Y. Li, B. Zhang, K. Huang, X. He, Y. Luo, R. Liang, H. Luo, X.L. Shen, W. Xu, Mitochondrial proteomic analysis reveals the molecular mechanisms underlying reproductive toxicity of zearalenone in MLTC-1 cells, Toxicology, 324 (2014) 55-67.

[63] P. Lin, F. Chen, J. Sun, J. Zhou, X. Wang, N. Wang, X. Li, Z. Zhang, A. Wang, Y. Jin, Mycotoxin zearalenone induces apoptosis in mouse Leydig cells via an endoplasmic reticulum stress-dependent signalling pathway, Reprod Toxicol, 52 (2015) 71-77.

[64] X. Han, R. Tang, X. Chen, B. Xu, Y. Qin, W. Wu, Y. Hu, L. Song, Y. Xia, X. Wang, 2,2',4,4'Tetrabromodiphenyl ether (BDE-47) decreases progesterone synthesis through cAMP-PKA pathway and P450scc downregulation in mouse Leydig tumor cells, Toxicology, 302 (2012) 44-50.

[65] S. Ohta, Y. Tabuchi, N. Yanai, S. Asano, H. Fuse, M. Obinata, Establishment of Leydig cell line, TTE1, from transgenic mice harboring temperature-sensitive simian virus 40 large T-antigen gene, Arch Androl, 48 (2002) 43-51.

[66] S. Ohta, H. Fuse, Y. Tabuchi, DNA microarray analysis of genes involved in the process of differentiation in mouse Leydig cell line TTE1, Arch Androl, 48 (2002) 203-208.

[67] K. Warita, T. Mitsuhashi, Y. Tabuchi, K. Ohta, S. Suzuki, N. Hoshi, T. Miki, Y. Takeuchi, Microarray and gene ontology analyses reveal downregulation of DNA repair and apoptotic pathways in diethylstilbestrol-exposed testicular Leydig cells, J Toxicol Sci, 37 (2012) 287-295. 
[68] K. Warita, T. Mitsuhashi, T. Sugawara, Y. Tabuchi, T. Tanida, Z.Y. Wang, Y. Matsumoto, T. Yokoyama, H. Kitagawa, T. Miki, Y. Takeuchi, N. Hoshi, Direct effects of diethylstilbestrol on the gene expression of the cholesterol side-chain cleavage enzyme (P450scc) in testicular Leydig cells, Life Sci, 87 (2010) 281-285.

[69] K. Kananen, M. Markkula, T. el-Hefnawy, F.P. Zhang, T. Paukku, J.G. Su, A.J. Hsueh, I. Huhtaniemi, The mouse inhibin alpha-subunit promoter directs SV40 T-antigen to Leydig cells in transgenic mice, Mol Cell Endocrinol, 119 (1996) 135-146.

[70] A.L. Forgacs, Q. Ding, R.G. Jaremba, I.T. Huhtaniemi, N.A. Rahman, T.R. Zacharewski, BLTK1 murine Leydig cells: a novel steroidogenic model for evaluating the effects of reproductive and developmental toxicants, Toxicol Sci, 127 (2012) 391-402.

[71] A.L. Forgacs, M.L. D'Souza, I.T. Huhtaniemi, N.A. Rahman, T.R. Zacharewski, Triazine herbicides and their chlorometabolites alter steroidogenesis in BLTK1 murine Leydig cells, Toxicol Sci, 134 (2013) 155-167.

[72] J.P. Mather, Establishment and characterization of two distinct mouse testicular epithelial cell lines, Biol Reprod, 23 (1980) 243-252.

[73] J.P. Mather, L.Z. Zhuang, V. Perez-Infante, D.M. Phillips, Culture of testicular cells in hormone-supplemented serum-free medium, Ann N Y Acad Sci, 383 (1982) 44-68.

[74] F.R. Musa, I. Takenaka, R. Konishi, M. Tokuda, Effects of luteinizing hormone, folliclestimulating hormone, and epidermal growth factor on expression and kinase activity of cyclindependent kinase 5 in Leydig TM3 and Sertoli TM4 cell lines, J Androl, 21 (2000) 392-402.

[75] V. Pezzi, R. Sirianni, A. Chimento, M. Maggiolini, S. Bourguiba, C. Delalande, S. Carreau, S. Ando, E.R. Simpson, C.D. Clyne, Differential expression of steroidogenic factor-1/adrenal 4 binding protein and liver receptor homolog-1 (LRH-1)/fetoprotein transcription factor in the rat testis: LRH-1 as a potential regulator of testicular aromatase expression, Endocrinology, 145 (2004) 2186-2196.

[76] J.J. Lysiak, J.L. Kirby, J.J. Tremblay, R.I. Woodson, M.A. Reardon, L.A. Palmer, T.T. Turner, Hypoxia-inducible factor-1alpha is constitutively expressed in murine Leydig cells and regulates 3beta-hydroxysteroid dehydrogenase type 1 promoter activity, J Androl, 30 (2009) 146-156.

[77] M. Otani, M. Kogo, S. Furukawa, S. Wakisaka, T. Maeda, The adiponectin paralog C1q/TNFrelated protein 3 (CTRP3) stimulates testosterone production through the cAMP/PKA signaling pathway, Cytokine, 58 (2012) 238-244.

[78] M. Maggi, P.L. Morris, S. Kassis, D. Rodbard, Identification and characterization of arginine vasopressin receptors in the clonal murine Leydig-derived TM3 cell line, Int J Androl, 12 (1989) 65-71. 
[79] A.M. Nakhla, C.W. Bardin, Y. Salomon, J.P. Mather, O.A. Janne, The actions of calcitonin on the TM3 Leydig cell line and on rat Leydig cell-enriched cultures, J Androl, 10 (1989) 311-320.

[80] C. Ying, Z. Zhang, S.Y. Ying, Expression and localization of activin beta A-subunit and activin receptors in TM3, a mouse Leydig cell line, Endocr Res, 21 (1995) 815-824.

[81] C.C. Taylor, D. Limback, P.F. Terranova, Src tyrosine kinase activity in rat thecal-interstitial cells and mouse TM3 Leydig cells is positively associated with cAMP-specific phosphodiesterase activity, Mol Cell Endocrinol, 126 (1997) 91-100.

[82] Y. Iwase, H. Fukata, C. Mori, Estrogenic compounds inhibit gap junctional intercellular communication in mouse Leydig TM3 cells, Toxicol Appl Pharmacol, 212 (2006) 237-246.

[83] S. Yoshida, S. Hirano, K. Shikagawa, S. Hirata, S. Rokuta, H. Takano, T. Ichinose, K. Takeda, Diesel exhaust particles suppress expression of sex steroid hormone receptors in TM3 mouse Leydig cells, Environ Toxicol Pharmacol, 24 (2007) 292-296.

[84] G. Bagchi, Y. Zhang, D.J. Waxman, Impact of methoxyacetic acid on mouse Leydig cell gene expression, Reprod Biol Endocrinol, 8 (2010) 65.

[85] B. Shen, W. Wang, L. Ding, Y. Sao, Y. Huang, Z. Shen, Y. Zhuo, Z. Wei, W. Zhang, Nuclear factor erythroid 2-related factor 2 rescues the oxidative stress induced by di-N-butylphthalate in testicular Leydig cells, Hum Exp Toxicol, 34 (2015) 145-152.

[86] B. Shen, W. Wang, L. Ma, S. Wang, L. Ding, Z. Chen, Y. Sao, H. Shen, Z. Wei, W. Zhang, Sulforaphane restores oxidative stress induced by di-N-butylphthalate in testicular Leydig cells with low basal reactive oxygen species levels, Urology, 84 (2014) 850-856.

[87] Y. Yasamura, A.H. Tashjian, Jr., G.H. Sato, Establishment of four functional, clonal strains of animal cells in culture, Science, 154 (1966) 1186-1189.

[88] S.I. Shin, Studies on interstitial cells in tissue culture: steroid biosynthesis in monolayers of mouse testicular interstitial cells, Endocrinology, 81 (1967) 440-448.

[89] L.A. Li, Polychlorinated biphenyl exposure and CYP19 gene regulation in testicular and adrenocortical cell lines, Toxicol In Vitro, 21 (2007) 1087-1094.

[90] H.K. Lee, M.S. Yoo, H.S. Choi, H.B. Kwon, J. Soh, Retinoic acids up-regulate steroidogenic acute regulatory protein gene, Mol Cell Endocrinol, 148 (1999) 1-10.

[91] K.H. Song, J.I. Park, M.O. Lee, J. Soh, K. Lee, H.S. Choi, LH induces orphan nuclear receptor Nur77 gene expression in testicular Leydig cells, Endocrinology, 142 (2001) 5116-5123.

[92] K.H. Song, K. Lee, H.S. Choi, Endocrine disrupter bisphenol a induces orphan nuclear receptor Nur77 gene expression and steroidogenesis in mouse testicular Leydig cells, Endocrinology, 143 (2002) 2208-2215. 
[93] S.Y. Park, C. Gomes, S.D. Oh, J. Soh, Cadmium up-regulates transcription of the steroidogenic acute regulatory protein (StAR) gene through phosphorylated CREB rather than SF-1 in K28 cells, J Toxicol Sci, 40 (2015) 151-161.

[94] S.I. Shin, Y. Yasumura, G.H. Sato, Studies on interstitial cells in tissue culture. II. Steroid biosynthesis by a clonal line of rat testicular interstitial cells, Endocrinology, 82 (1968) 614-616.

[95] D.A. Freeman, Constitutive steroidogenesis in the R2C Leydig tumor cell line is maintained by the adenosine 3',5'-cyclic monophosphate-independent production of a cycloheximide-sensitive factor that enhances mitochondrial pregnenolone biosynthesis, Endocrinology, 120 (1987) 124-132. [96] R.M. Rao, Y. Jo, M. Babb-Tarbox, P.J. Syapin, D.M. Stocco, Regulation of steroid hormone biosynthesis in R2C and MA-10 Leydig tumor cells: role of the cholesterol transfer proteins StAR and PBR, Endocr Res, 28 (2002) 387-394.

[97] R. Barone, F. Macaluso, P. Catanese, A. Marino Gammazza, L. Rizzuto, P. Marozzi, G. Lo Giudice, T. Stampone, F. Cappello, G. Morici, G. Zummo, F. Farina, V. Di Felice, Endurance exercise and conjugated linoleic acid (CLA) supplementation up-regulate CYP17A1 and stimulate testosterone biosynthesis, PLoS One, 8 (2013) e79686.

[98] P. Balbuena, J. Campbell, Jr., H.J. Clewell, 3rd, R.A. Clewell, Evaluation of a predictive in vitro Leydig cell assay for anti-androgenicity of phthalate esters in the rat, Toxicol In Vitro, 27 (2013) 1711-1718.

[99] Q. Zhang, P. Zou, H. Zhan, M. Zhang, L. Zhang, R.S. Ge, Y. Huang, Dihydrolipoamide dehydrogenase and cAMP are associated with cadmium-mediated Leydig cell damage, Toxicol Lett, 205 (2011) 183-189.

[100] T.L. Rizner, H. Sasano, M.H. Choi, A. Odermatt, J. Adamski, Recommendations for description and validation of antibodies for research use, J Steroid Biochem Mol Biol, 156 (2015) 40-42.

[101] D.M. Stocco, W. Chen, Presence of identical mitochondrial proteins in unstimulated constitutive steroid-producing $\mathrm{R} 2 \mathrm{C}$ rat Leydig tumor and stimulated nonconstitutive steroidproducing MA-10 mouse Leydig tumor cells, Endocrinology, 128 (1991) 1918-1926.

[102] K.M. Doody, B.A. Murry, J.I. Mason, The use of rat Leydig tumor (R2C) and human hepatoma (HEPG2) cells to evaluate potential inhibitors of rat and human steroid aromatase, J Enzyme Inhib, 4 (1990) 153-158.

[103] M. Heneweer, M. van den Berg, J.T. Sanderson, A comparison of human H295R and rat R2C cell lines as in vitro screening tools for effects on aromatase, Toxicol Lett, 146 (2004) 183-194. 
[104] J.Y. Kim, E.H. Han, H.G. Kim, K.N. Oh, S.K. Kim, K.Y. Lee, H.G. Jeong, Bisphenol Ainduced aromatase activation is mediated by cyclooxygenase-2 up-regulation in rat testicular Leydig cells, Toxicol Lett, 193 (2010) 200-208.

[105] A. Chimento, R. Sirianni, F. Zolea, A. De Luca, M. Lanzino, S. Catalano, S. Ando, V. Pezzi, Nandrolone and stanozolol induce Leydig cell tumor proliferation through an estrogen-dependent mechanism involving IGF-I system, J Cell Physiol, 227 (2012) 2079-2088.

[106] P. Maris, A. Campana, I. Barone, C. Giordano, C. Morelli, R. Malivindi, D. Sisci, S. Aquila, V. Rago, D. Bonofiglio, S. Catalano, M. Lanzino, S. Ando, Androgens inhibit aromatase expression through DAX-1: insights into the molecular link between hormone balance and Leydig cancer development, Endocrinology, 156 (2015) 1251-1262.

[107] T. Wahlstrom, I. Huhtaniemi, O. Hovatta, M. Seppala, Localization of luteinizing hormone, follicle-stimulating hormone, prolactin, and their receptors in human and rat testis using immunohistochemistry and radioreceptor assay, J Clin Endocrinol Metab, 57 (1983) 825-830.

[108] A.K. Christensen, K.C. Peacock, Increase in Leydig cell number in testes of adult rats treated chronically with an excess of human chorionic gonadotropin, Biol Reprod, 22 (1980) 383-391.

[109] C.G. Heller, D.R. Leach, Quantification of Leydig cells and measurement of Leydig-cell size following administration of human chorionic gonadotrophin to normal men, J Reprod Fertil, 25 (1971) 185-192.

[110] B.J. Simpson, F.C. Wu, R.M. Sharpe, Isolation of human Leydig cells which are highly responsive to human chorionic gonadotropin, J Clin Endocrinol Metab, 65 (1987) 415-422.

[111] R.N. Clayton, I.T. Huhtaniemi, Absence of gonadotropin-releasing hormone receptors in human gonadal tissue, Nature, 299 (1982) 56-59.

[112] N.G. Wang, K. Sundaram, S. Pavlou, J. Rivier, W. Vale, C.W. Bardin, Mice are insensitive to the antitesticular effects of luteinizing hormone-releasing hormone agonists, Endocrinology, 112 (1983) 331-335.

[113] R. Habert, V. Muczynski, T. Grisin, D. Moison, S. Messiaen, R. Frydman, A. Benachi, G. Delbes, R. Lambrot, A. Lehraiki, T. N'Tumba-Byn, M.J. Guerquin, C. Levacher, V. Rouiller-Fabre, G. Livera, Concerns about the widespread use of rodent models for human risk assessments of endocrine disruptors, Reproduction, 147 (2014) R119-129.

[114] R. Lambrot, V. Muczynski, C. Lecureuil, G. Angenard, H. Coffigny, C. Pairault, D. Moison, R. Frydman, R. Habert, V. Rouiller-Fabre, Phthalates impair germ cell development in the human fetal testis in vitro without change in testosterone production, Environ Health Perspect, 117 (2009) $32-37$. 
[115] N.E. Heger, S.J. Hall, M.A. Sandrof, E.V. McDonnell, J.B. Hensley, E.N. McDowell, K.A. Martin, K.W. Gaido, K.J. Johnson, K. Boekelheide, Human fetal testis xenografts are resistant to phthalate-induced endocrine disruption, Environ Health Perspect, 120 (2012) 1137-1143.

[116] R.T. Mitchell, A.J. Childs, R.A. Anderson, S. van den Driesche, P.T. Saunders, C. McKinnell, W.H. Wallace, C.J. Kelnar, R.M. Sharpe, Do phthalates affect steroidogenesis by the human fetal testis? Exposure of human fetal testis xenografts to di-n-butyl phthalate, J Clin Endocrinol Metab, 97 (2012) E341-348.

[117] R.T. Mitchell, R.M. Sharpe, R.A. Anderson, C. McKinnell, S. Macpherson, L.B. Smith, W.H. Wallace, C.J. Kelnar, S. van den Driesche, Diethylstilboestrol exposure does not reduce testosterone production in human fetal testis xenografts, PLoS One, 8 (2013) e61726.

[118] T. N'Tumba-Byn, D. Moison, M. Lacroix, C. Lecureuil, L. Lesage, S.M. Prud'homme, S. Pozzi-Gaudin, R. Frydman, A. Benachi, G. Livera, V. Rouiller-Fabre, R. Habert, Differential effects of bisphenol A and diethylstilbestrol on human, rat and mouse fetal leydig cell function, PLoS One, 7 (2012) e51579.

[119] G. Delbes, C. Duquenne, J. Szenker, J. Taccoen, R. Habert, C. Levacher, Developmental changes in testicular sensitivity to estrogens throughout fetal and neonatal life, Toxicol Sci, 99 (2007) 234-243.

[120] P. Tartarin, D. Moison, E. Guibert, J. Dupont, R. Habert, V. Rouiller-Fabre, N. Frydman, S. Pozzi, R. Frydman, C. Lecureuil, P. Froment, Metformin exposure affects human and mouse fetal testicular cells, Hum Reprod, 27 (2012) 3304-3314.

[121] E.K. Barthelmess, R.K. Naz, Polycystic ovary syndrome: current status and future perspective, Front Biosci (Elite Ed), 6 (2014) 104-119.

[122] A. Mlynarcikova, M. Fickova, S. Scsukova, Impact of endocrine disruptors on ovarian steroidogenesis, Endocr Regul, 48 (2014) 201-224.

[123] A.M. Calafat, X. Ye, L.Y. Wong, J.A. Reidy, L.L. Needham, Exposure of the U.S. population to bisphenol A and 4-tertiary-octylphenol: 2003-2004, Environ Health Perspect, 116 (2008) 39-44.

[124] B.L. Sprague, A. Trentham-Dietz, C.J. Hedman, J. Wang, J.D. Hemming, J.M. Hampton, D.S. Buist, E.J. Aiello Bowles, G.S. Sisney, E.S. Burnside, Circulating serum xenoestrogens and mammographic breast density, Breast Cancer Res, 15 (2013) R45.

[125] Y. Ikezuki, O. Tsutsumi, Y. Takai, Y. Kamei, Y. Taketani, Determination of bisphenol A concentrations in human biological fluids reveals significant early prenatal exposure, Hum Reprod, 17 (2002) 2839-2841.

[126] E. De Felip, A. di Domenico, R. Miniero, L. Silvestroni, Polychlorobiphenyls and other organochlorine compounds in human follicular fluid, Chemosphere, 54 (2004) 1445-1449. 
[127] J.D. Meeker, S.A. Missmer, L. Altshul, A.F. Vitonis, L. Ryan, D.W. Cramer, R. Hauser, Serum and follicular fluid organochlorine concentrations among women undergoing assisted reproduction technologies, Environ Health, 8 (2009) 32.

[128] E.L. Gregoraszczuk, Dioxin exposure and porcine reproductive hormonal activity, Cad Saude Publica, 18 (2002) 453-462.

[129] W.S. Stokes, Selecting appropriate animal models and experimental designs for endocrine disruptor research and testing studies, Ilar J, 45 (2004) 387-393.

[130] S. Lenie, J. Smitz, Steroidogenesis-disrupting compounds can be effectively studied for major fertility-related endpoints using in vitro cultured mouse follicles, Toxicol Lett, 185 (2009) 143-152. [131] A. Mlynarcikova, M. Fickova, S. Scsukova, The effects of selected phenol and phthalate derivatives on steroid hormone production by cultured porcine granulosa cells, Altern Lab Anim, 35 (2007) 71-77.

[132] M. Breckwoldt, N. Selvaraj, D. Aharoni, A. Barash, I. Segal, V. Insler, A. Amsterdam, Expression of Ad4-BP/cytochrome P450 side chain cleavage enzyme and induction of cell death in long-term cultures of human granulosa cells, Mol Hum Reprod, 2 (1996) 391-400.

[133] F. Jacob, S. Nixdorf, N.F. Hacker, V.A. Heinzelmann-Schwarz, Reliable in vitro studies require appropriate ovarian cancer cell lines, J Ovarian Res, 7 (2014) 60.

[134] J.C. Havelock, W.E. Rainey, B.R. Carr, Ovarian granulosa cell lines, Mol Cell Endocrinol, 228 (2004) 67-78.

[135] K. Kananen, M. Markkula, E. Rainio, J.G. Su, A.J. Hsueh, I.T. Huhtaniemi, Gonadal tumorigenesis in transgenic mice bearing the mouse inhibin alpha-subunit promoter/simian virus $\mathrm{T}$ antigen fusion gene: characterization of ovarian tumors and establishment of gonadotropinresponsive granulosa cell lines, Mol Endocrinol, 9 (1995) 616-627.

[136] D. Gunnarsson, P. Leffler, E. Ekwurtzel, G. Martinsson, K. Liu, G. Selstam, Mono-(2ethylhexyl) phthalate stimulates basal steroidogenesis by a cAMP-independent mechanism in mouse gonadal cells of both sexes, Reproduction, 135 (2008) 693-703.

[137] T.W. Briers, A. van de Voorde, H. Vanderstichele, Characterization of immortalized mouse granulosa cell lines, In Vitro Cell Dev Biol Anim, 29A (1993) 847-854.

[138] H. Vanderstichele, B. Delaey, J. de Winter, F. de Jong, L. Rombauts, G. Verhoeven, C. Dello, A. van de Voorde, T. Briers, Secretion of steroids, growth factors, and cytokines by immortalized mouse granulosa cell lines, Biol Reprod, 50 (1994) 1190-1202.

[139] P.K. Kreeger, T.K. Woodruff, L.D. Shea, Murine granulosa cell morphology and function are regulated by a synthetic Arg-Gly-Asp matrix, Mol Cell Endocrinol, 205 (2003) 1-10. 
[140] K. Tajima, K. Hosokawa, Y. Yoshida, A. Dantes, R. Sasson, F. Kotsuji, A. Amsterdam, Establishment of FSH-responsive cell lines by transfection of pre-ovulatory human granulosa cells with mutated p53 (p53val135) and Ha-ras genes, Mol Hum Reprod, 8 (2002) 48-57.

[141] R. Sasson, K. Tajima, A. Amsterdam, Glucocorticoids protect against apoptosis induced by serum deprivation, cyclic adenosine 3',5'-monophosphate and p53 activation in immortalized human granulosa cells: involvement of Bcl-2, Endocrinology, 142 (2001) 802-811.

[142] S.M. Salih, M. Jamaluddin, S.A. Salama, A.A. Fadl, M. Nagamani, A. Al-Hendy, Regulation of catechol O-methyltransferase expression in granulosa cells: a potential role for follicular arrest in polycystic ovary syndrome, Fertil Steril, 89 (2008) 1414-1421.

[143] S.S. Patel, V.E. Beshay, J.C. Escobar, T. Suzuki, B.R. Carr, Molecular mechanism for repression of 17alpha-hydroxylase expression and androstenedione production in granulosa cells, $\mathrm{J}$ Clin Endocrinol Metab, 94 (2009) 5163-5168.

[144] K. Hosokawa, A. Dantes, C. Schere-Levy, A. Barash, Y. Yoshida, F. Kotsuji, I. Vlodavsky, A. Amsterdam, Induction of Ad4BP/SF-1, steroidogenic acute regulatory protein, and cytochrome P450scc enzyme system expression in newly established human granulosa cell lines, Endocrinology, 139 (1998) 4679-4687.

[145] I. Ishiwata, C. Ishiwata, M. Soma, N. Kobayashi, H. Ishikawa, Establishment and characterization of an estrogen-producing human ovarian granulosa tumor cell line, J Natl Cancer Inst, 72 (1984) 789-800.

[146] H. Zhang, M. Vollmer, M. De Geyter, Y. Litzistorf, A. Ladewig, M. Durrenberger, R. Guggenheim, P. Miny, W. Holzgreve, C. De Geyter, Characterization of an immortalized human granulosa cell line (COV434), Mol Hum Reprod, 6 (2000) 146-153.

[147] R.M. Navalakhe, D.D. Jagtap, S.U. Nayak, T.D. Nandedkar, S.D. Mahale, Effect of FSH receptor-binding inhibitor-8 on FSH-mediated granulosa cell signaling and proliferation, Chem Biol Drug Des, 82 (2013) 178-188.

[148] N. Mansouri-Attia, R. James, A. Ligon, X. Li, S.A. Pangas, Soy promotes juvenile granulosa cell tumor development in mice and in the human granulosa cell tumor-derived COV434 cell line, Biol Reprod, 91 (2014) 100.

[149] L. Cloix, M. Reverchon, M. Cornuau, P. Froment, C. Rame, C. Costa, G. Froment, P. Lecomte, W. Chen, D. Royere, F. Guerif, J. Dupont, Expression and regulation of INTELECTIN1 in human granulosa-lutein cells: role in IGF-1-induced steroidogenesis through NAMPT, Biol Reprod, 91 (2014) 50.

[150] T. Mizutani, Y. Ju, Y. Imamichi, T. Osaki, T. Yazawa, S. Kawabe, S. Ishikane, T. Matsumura, M. Kanno, Y. Kamiki, K. Kimura, N. Minamino, K. Miyamoto, C/EBPbeta 
(CCAAT/enhancer-binding protein beta) mediates progesterone production through transcriptional regulation in co-operation with SF-1 (steroidogenic factor-1), Biochem J, 460 (2014) 459-471.

[151] S. Kawabe, T. Yazawa, M. Kanno, Y. Usami, T. Mizutani, Y. Imamichi, Y. Ju, T. Matsumura, M. Orisaka, K. Miyamoto, A novel isoform of liver receptor homolog-1 is regulated by steroidogenic factor-1 and the specificity protein family in ovarian granulosa cells, Endocrinology, 154 (2013) 1648-1660.

[152] M. Reverchon, M. Cornuau, L. Cloix, C. Rame, F. Guerif, D. Royere, J. Dupont, Visfatin is expressed in human granulosa cells: regulation by metformin through AMPK/SIRT1 pathways and its role in steroidogenesis, Mol Hum Reprod, 19 (2013) 313-326.

[153] H.M. Chang, J.C. Cheng, C. Klausen, P.C. Leung, BMP15 suppresses progesterone production by down-regulating StAR via ALK3 in human granulosa cells, Mol Endocrinol, 27 (2013) 2093-2104.

[154] G. Irusta, M.C. Pazos, D. Abramovich, I. De Zuniga, F. Parborell, M. Tesone, Effects of an inhibitor of the gamma-secretase complex on proliferation and apoptotic parameters in a FOXL2mutated granulosa tumor cell line (KGN), Biol Reprod, 89 (2013) 9.

[155] D. Fu, X. Lv, G. Hua, C. He, J. Dong, S.M. Lele, D.W. Li, Q. Zhai, J.S. Davis, C. Wang, YAP regulates cell proliferation, migration, and steroidogenesis in adult granulosa cell tumors, Endocr Relat Cancer, 21 (2014) 297-310.

[156] J. Kwintkiewicz, Y. Nishi, T. Yanase, L.C. Giudice, Peroxisome proliferator-activated receptor-gamma mediates bisphenol A inhibition of FSH-stimulated IGF-1, aromatase, and estradiol in human granulosa cells, Environ Health Perspect, 118 (2010) 400-406.

[157] M. Watanabe, S. Ohno, S. Nakajin, Effects of bisphenol A on the expression of cytochrome P450 aromatase (CYP19) in human fetal osteoblastic and granulosa cell-like cell lines, Toxicol Lett, 210 (2012) 95-99.

[158] J. Ernst, J.C. Jann, R. Biemann, H.M. Koch, B. Fischer, Effects of the environmental contaminants DEHP and TCDD on estradiol synthesis and aryl hydrocarbon receptor and peroxisome proliferator-activated receptor signalling in the human granulosa cell line $\mathrm{KGN}, \mathrm{Mol}$ Hum Reprod, 20 (2014) 919-928.

[159] W. Fan, T. Yanase, H. Morinaga, S. Gondo, T. Okabe, M. Nomura, T. Komatsu, K. Morohashi, T.B. Hayes, R. Takayanagi, H. Nawata, Atrazine-induced aromatase expression is SF-1 dependent: implications for endocrine disruption in wildlife and reproductive cancers in humans, Environ Health Perspect, 115 (2007) 720-727.

[160] S. Park, S. Kim, H. Jin, K. Lee, J. Bae, Impaired development of female mouse offspring maternally exposed to simazine, Environ Toxicol Pharmacol, 38 (2014) 845-851. 
[161] W.L. Miller, A brief history of adrenal research: steroidogenesis - the soul of the adrenal, Mol Cell Endocrinol, 371 (2013) 5-14.

[162] P.W. Harvey, D.J. Everett, The adrenal cortex and steroidogenesis as cellular and molecular targets for toxicity: critical omissions from regulatory endocrine disrupter screening strategies for human health?, J Appl Toxicol, 23 (2003) 81-87.

[163] P.W. Harvey, D.J. Everett, C.J. Springall, Adrenal toxicology: a strategy for assessment of functional toxicity to the adrenal cortex and steroidogenesis, J Appl Toxicol, 27 (2007) 103-115.

[164] P.W. Harvey, C. Sutcliffe, Adrenocortical hypertrophy: establishing cause and toxicological significance, J Appl Toxicol, 30 (2010) 617-626.

[165] J.P. Hinson, P.W. Raven, Effects of endocrine-disrupting chemicals on adrenal function, Best Pract Res Clin Endocrinol Metab, 20 (2006) 111-120.

[166] FDA, Endocrine disruption potential of drugs: nonclinical evaluation, Draft Guidance, Federal Register 78, 183 (2013) 57859.

[167] P.W. Harvey, Adrenocortical endocrine disruption, J Steroid Biochem Mol Biol, 155 (2016) 199-206.

[168] D.B. Martinez-Arguelles, V. Papadopoulos, Mechanisms mediating environmental chemicalinduced endocrine disruption in the adrenal gland, Front Endocrinol (Lausanne), 6 (2015) 29.

[169] O.g.f.t.t.o. chemicals., Test No. 456: H295R Steroidogenesis Assay, OECD Guidelines for the Testing of Chemicals, Section 4: Health Effects, (2011).

[170] A.F. Gazdar, H.K. Oie, C.H. Shackleton, T.R. Chen, T.J. Triche, C.E. Myers, G.P. Chrousos, M.F. Brennan, C.A. Stein, R.V. La Rocca, Establishment and characterization of a human adrenocortical carcinoma cell line that expresses multiple pathways of steroid biosynthesis, Cancer Res, 50 (1990) 5488-5496.

[171] W.E. Rainey, I.M. Bird, J.I. Mason, The NCI-H295 cell line: a pluripotent model for human adrenocortical studies, Mol Cell Endocrinol, 100 (1994) 45-50.

[172] W.E. Rainey, I.M. Bird, C. Sawetawan, N.A. Hanley, J.L. McCarthy, E.A. McGee, R. Wester, J.I. Mason, Regulation of human adrenal carcinoma cell (NCI-H295) production of C19 steroids, J Clin Endocrinol Metab, 77 (1993) 731-737.

[173] W.E. Rainey, K. Saner, B.P. Schimmer, Adrenocortical cell lines, Mol Cell Endocrinol, 228 (2004) 23-38.

[174] B. Staels, D.W. Hum, W.L. Miller, Regulation of steroidogenesis in NCI-H295 cells: a cellular model of the human fetal adrenal, Mol Endocrinol, 7 (1993) 423-433. 
[175] H. Rodriguez, D.W. Hum, B. Staels, W.L. Miller, Transcription of the human genes for cytochrome P450scc and P450c17 is regulated differently in human adrenal NCI-H295 cells than in mouse adrenal Y1 cells, J Clin Endocrinol Metab, 82 (1997) 365-371.

[176] T. Wang, J.G. Rowland, J. Parmar, M. Nesterova, T. Seki, W.E. Rainey, Comparison of aldosterone production among human adrenocortical cell lines, Horm Metab Res, 44 (2012) 245250.

[177] J. Parmar, R.E. Key, W.E. Rainey, Development of an adrenocorticotropin-responsive human adrenocortical carcinoma cell line, J Clin Endocrinol Metab, 93 (2008) 4542-4546.

[178] T. Wang, W.E. Rainey, Human adrenocortical carcinoma cell lines, Mol Cell Endocrinol, 351 (2012) 58-65.

[179] Y. Xing, M.A. Edwards, C. Ahlem, M. Kennedy, A. Cohen, C.E. Gomez-Sanchez, W.E. Rainey, The effects of ACTH on steroid metabolomic profiles in human adrenal cells, J Endocrinol, 209 (2011) 327-335.

[180] I.M. Bird, N.A. Hanley, R.A. Word, J.M. Mathis, J.L. McCarthy, J.I. Mason, W.E. Rainey, Human NCI-H295 adrenocortical carcinoma cells: a model for angiotensin-II-responsive aldosterone secretion, Endocrinology, 133 (1993) 1555-1561.

[181] B.J. Clark, S.C. Soo, K.M. Caron, Y. Ikeda, K.L. Parker, D.M. Stocco, Hormonal and developmental regulation of the steroidogenic acute regulatory protein, Mol Endocrinol, 9 (1995) 1346-1355.

[182] H. Otani, F. Otsuka, K. Inagaki, J. Suzuki, T. Miyoshi, Y. Kano, J. Goto, T. Ogura, H. Makino, Aldosterone breakthrough caused by chronic blockage of angiotensin II type 1 receptors in human adrenocortical cells: possible involvement of bone morphogenetic protein-6 actions, Endocrinology, 149 (2008) 2816-2825.

[183] E.F. Nogueira, W.B. Bollag, W.E. Rainey, Angiotensin II regulation of adrenocortical gene transcription, Mol Cell Endocrinol, 302 (2009) 230-236.

[184] E.F. Nogueira, C.A. Vargas, M. Otis, N. Gallo-Payet, W.B. Bollag, W.E. Rainey, Angiotensin-II acute regulation of rapid response genes in human, bovine, and rat adrenocortical cells, J Mol Endocrinol, 39 (2007) 365-374.

[185] E. Samandari, P. Kempna, J.M. Nuoffer, G. Hofer, P.E. Mullis, C.E. Fluck, Human adrenal corticocarcinoma NCI-H295R cells produce more androgens than NCI-H295A cells and differ in 3beta-hydroxysteroid dehydrogenase type 2 and 17,20 lyase activities, J Endocrinol, 195 (2007) 459-472. 
[186] S.H. Mellon, N. Compagnone, M. Sander, C. Cover, D. Ganten, B. Djavidani, Rodent models for studying steroids and hypertension: from fetal development to cells in culture, Steroids, 60 (1995) 59-64.

[187] S.H. Mellon, W.L. Miller, S.R. Bair, C.C. Moore, J.L. Vigne, R.I. Weiner, Steroidogenic adrenocortical cell lines produced by genetically targeted tumorigenesis in transgenic mice, Mol Endocrinol, 8 (1994) 97-108.

[188] N.A. Compagnone, S.R. Bair, S.H. Mellon, Characterization of adrenocortical cell lines produced by genetically targeted tumorigenesis in transgenic mice, Steroids, 62 (1997) 238-243.

[189] B.P. Schimmer, M. Cordova, H. Cheng, A. Tsao, A.B. Goryachev, A.D. Schimmer, Q. Morris, Global profiles of gene expression induced by adrenocorticotropin in Y1 mouse adrenal cells, Endocrinology, 147 (2006) 2357-2367.

[190] B. Ragazzon, A.M. Lefrancois-Martinez, P. Val, I. Sahut-Barnola, C. Tournaire, C. Chambon, J.L. Gachancard-Bouya, R.J. Begue, G. Veyssiere, A. Martinez, Adrenocorticotropin-dependent changes in SF-1/DAX-1 ratio influence steroidogenic genes expression in a novel model of glucocorticoid-producing adrenocortical cell lines derived from targeted tumorigenesis, Endocrinology, 147 (2006) 1805-1818.

[191] K. Hilscherova, P.D. Jones, T. Gracia, J.L. Newsted, X. Zhang, J.T. Sanderson, R.M. Yu, R.S. Wu, J.P. Giesy, Assessment of the effects of chemicals on the expression of ten steroidogenic genes in the H295R cell line using real-time PCR, Toxicol Sci, 81 (2004) 78-89.

[192] A. Oskarsson, E. Ulleras, K.E. Plant, J.P. Hinson, P.S. Goldfarb, Steroidogenic gene expression in H295R cells and the human adrenal gland: adrenotoxic effects of lindane in vitro, $\mathrm{J}$ Appl Toxicol, 26 (2006) 484-492.

[193] T. Gracia, K. Hilscherova, P.D. Jones, J.L. Newsted, E.B. Higley, X. Zhang, M. Hecker, M.B. Murphy, R.M. Yu, P.K. Lam, R.S. Wu, J.P. Giesy, Modulation of steroidogenic gene expression and hormone production of H295R cells by pharmaceuticals and other environmentally active compounds, Toxicol Appl Pharmacol, 225 (2007) 142-153.

[194] T. Gracia, K. Hilscherova, P.D. Jones, J.L. Newsted, X. Zhang, M. Hecker, E.B. Higley, J.T. Sanderson, R.M. Yu, R.S. Wu, J.P. Giesy, The H295R system for evaluation of endocrinedisrupting effects, Ecotoxicol Environ Saf, 65 (2006) 293-305.

[195] D.M. Rotroff, D.J. Dix, K.A. Houck, T.B. Knudsen, M.T. Martin, K.W. McLaurin, D.M. Reif, K.M. Crofton, A.V. Singh, M. Xia, R. Huang, R.S. Judson, Using in vitro high throughput screening assays to identify potential endocrine-disrupting chemicals, Environ Health Perspect, 121 (2013) 7-14. 
[196] M.W. van den Dungen, J.C. Rijk, E. Kampman, W.T. Steegenga, A.J. Murk, Steroid hormone related effects of marine persistent organic pollutants in human H295R adrenocortical carcinoma cells, Toxicol In Vitro, 29 (2015) 769-778.

[197] E. Ulleras, A. Ohlsson, A. Oskarsson, Secretion of cortisol and aldosterone as a vulnerable target for adrenal endocrine disruption - screening of 30 selected chemicals in the human H295R cell model, J Appl Toxicol, 28 (2008) 1045-1053.

[198] J.M. Maglich, M. Kuhn, R.E. Chapin, M.T. Pletcher, More than just hormones: H295R cells as predictors of reproductive toxicity, Reprod Toxicol, 45 (2014) 77-86.

[199] M. Hecker, J.L. Newsted, M.B. Murphy, E.B. Higley, P.D. Jones, R. Wu, J.P. Giesy, Human adrenocarcinoma (H295R) cells for rapid in vitro determination of effects on steroidogenesis: hormone production, Toxicol Appl Pharmacol, 217 (2006) 114-124.

[200] C.S. Winther, F.K. Nielsen, M. Hansen, B. Styrishave, Corticosteroid production in H295R cells during exposure to 3 endocrine disrupters analyzed with LC-MS/MS, Int J Toxicol, 32 (2013) 219-227.

[201] D. Tonoli, C. Furstenberger, J. Boccard, D. Hochstrasser, F. Jeanneret, A. Odermatt, S. Rudaz, Steroidomic Footprinting Based on Ultra-High Performance Liquid Chromatography Coupled with Qualitative and Quantitative High-Resolution Mass Spectrometry for the Evaluation of Endocrine Disrupting Chemicals in H295R Cells, Chem Res Toxicol, 28 (2015) 955-966.

[202] N.G. Hattangady, L.O. Olala, W.B. Bollag, W.E. Rainey, Acute and chronic regulation of aldosterone production, Mol Cell Endocrinol, 350 (2012) 151-162.

[203] D. Tonoli, C. Furstenberger, J. Boccard, D. Hochstrasser, F. Jeanneret, A. Odermatt, S. Rudaz, Steroidomic Footprinting Based on Ultra-High Performance Liquid Chromatography Coupled with Qualitative and Quantitative High-Resolution Mass Spectrometry for the Evaluation of Endocrine Disrupting Chemicals in H295R Cells, Chem Res Toxicol, 28 (2015) 955-966.

[204] J.C. Rijk, A.A. Peijnenburg, M.H. Blokland, A. Lommen, R.L. Hoogenboom, T.F. Bovee, Screening for modulatory effects on steroidogenesis using the human H295R adrenocortical cell line: a metabolomics approach, Chem Res Toxicol, 25 (2012) 1720-1731.

[205] M. Reitsma, T.F. Bovee, A.A. Peijnenburg, P.J. Hendriksen, R.L. Hoogenboom, J.C. Rijk, Endocrine-disrupting effects of thioxanthone photoinitiators, Toxicol Sci, 132 (2013) 64-74.

[206] F.K. Nielsen, C.H. Hansen, J.A. Fey, M. Hansen, N.W. Jacobsen, B. Halling-Sorensen, E. Bjorklund, B. Styrishave, H295R cells as a model for steroidogenic disruption: a broader perspective using simultaneous chemical analysis of 7 key steroid hormones, Toxicol In Vitro, 26 (2012) 343-350. 
[207] J.G. Teeguarden, S. Hanson-Drury, A systematic review of Bisphenol A "low dose" studies in the context of human exposure: a case for establishing standards for reporting "low-dose" effects of chemicals, Food Chem Toxicol, 62 (2013) 935-948. 
Figure legends

Figure 1: Schematic overview of adrenal steroidogenesis. Major steroids produced are indicated in bold and by solid lines, minor metabolites are indicated by dashed lines.

Figure 2: Schematic overview of steroidogenesis in Leydig cells.

Figure 3: Schematic overview of ovarian steroidogenesis. 
Figure 1

\section{Adrenal Gland}

\section{Zona Reticularis}

Pregnenolone

17a-Hydroxypregnenolone

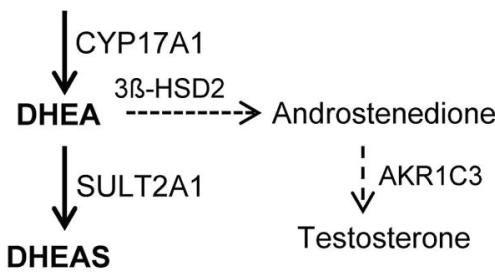

\section{Zona Fasciculata}

17a-Hydroxypregnenolone $\longleftarrow$ Pregnenolone

$\downarrow^{3 ß-H S D 2}$

17a-Hydroxyprogesterone

CYP17A1

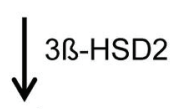

$\downarrow$ CYP21A2

11-Deoxycortisol

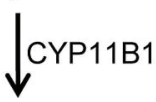

Cortisol
CYP21A2

CYP17A1

Progesterone

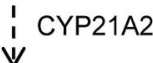

11-Deoxycorticosteron

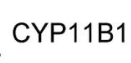

Corticosterone

\section{Zona Glomerulosa}

Pregnenolone

$$
\downarrow 3 \text { 3ß-HSD2 }
$$

\section{Progesterone}

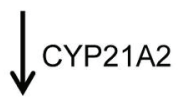

11-Deoxycorticosterone

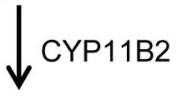

Corticosterone

CYP11B2

Aldosterone 


\section{Leydig Cell}

Pregnenolone

$$
\downarrow \text { CYP17A1 }
$$

17a-Hydroxypregnenolone

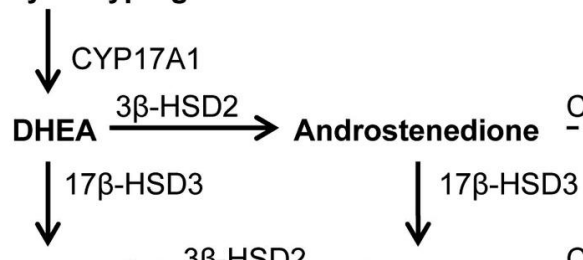

Androstenediol $\stackrel{3 \beta-H S D 2}{\longrightarrow}$ Testosterone $\stackrel{\text { CYP19A1 }}{\longrightarrow} \rightarrow$ Estradiol 
Granulosa Cell

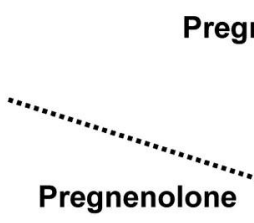

CYP17A1

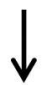

17a-Hydroxypregnenolone CYP17A1 DHEA 3ß-HSD2

CYP19A1

Estrone $\stackrel{17 \beta-H S D 1}{\longrightarrow}$ Estradiol 3ß-HSD2

$\rightarrow$ Androstenedione
Corpus Luteum

$3 \beta-H S D 2$
Progesterone

17ß-HSD1

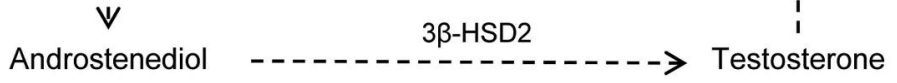

